\title{
Novel Nanocombinations of L-Tryptophan and L-Cysteine: Preparation, Characterization, and Their Applications for Antimicrobial and Anticancer Activities
}

\author{
Ahmed I. Abd-Elhamid ${ }^{1}\left(\mathbb{D}\right.$, Hamada El-Gendi ${ }^{2, *}$, Abdallah E. Abdallah $^{3}$ and Esmail M. El-Fakharany ${ }^{4, *(\mathbb{D}}$ \\ 1 Composites and Nanostructured Materials Research Department, Advanced Technology and New Materials \\ Research Institute, City of Scientific Research and Technological Applications (SRTA City), \\ New Borg El-Arab 21934, Egypt; ahm_ch_ibr@yahoo.com \\ 2 Bioprocess Development Department, Genetic Engineering and Biotechnology Research Institute, \\ City of Scientific Research and Technological Applications (SRTA City), New Borg El-Arab 21934, Egypt \\ 3 Pharmaceutical Medicinal Chemistry \& Drug Design Department, Faculty of Pharmacy (Boys), \\ Al-Azhar University, Cairo 11884, Egypt; abdulla_emara@azhar.edu.eg \\ 4 Protein Research Department, Genetic Engineering and Biotechnology Research Institute GEBRI, \\ City of Scientific Research and Technological Applications (SRTA City), New Borg El-Arab 21934, Egypt \\ * Correspondence: elgendi981@yahoo.com (H.E.-G.); esmailelfakharany@yahoo.co.uk (E.M.E.-F.)
}

\section{check for} updates

Citation: Abd-Elhamid, A.I.; El-Gendi, H.; Abdallah, A.E.; El-Fakharany, E.M. Novel Nanocombinations of L-Tryptophan and L-Cysteine: Preparation,

Characterization, and Their Applications for Antimicrobial and Anticancer Activities. Pharmaceutics 2021, 13, 1595. https://doi.org/ 10.3390/pharmaceutics13101595

Academic Editor: Dong-Hyun Kim

Received: 7 August 2021

Accepted: 24 September 2021

Published: 1 October 2021

Publisher's Note: MDPI stays neutral with regard to jurisdictional claims in published maps and institutional affiliations.

Copyright: (c) 2021 by the authors. Licensee MDPI, Basel, Switzerland. This article is an open access article distributed under the terms and conditions of the Creative Commons Attribution (CC BY) license (https:// creativecommons.org/licenses/by/ $4.0 /)$.

\begin{abstract}
Tungsten oxide $\mathrm{WO}_{3}$ nanoparticles (NPs) were prepared in a form of nanosheets with homogeneous size and dimensions in one step through acid precipitation using a cation exchange column. The resulting $\mathrm{WO}_{3}$ nanosheet surface was decorated with one of the two amino acids (AAs) L-tryptophan (Trp) or L-cysteine (Cys) and evaluated for their dye removal, antimicrobial, and antitumor activities. A noticeable improvement in the biological activity of $\mathrm{WO}_{3} \mathrm{NPs}$ was detected upon amino acid modification compared to the original $\mathrm{WO}_{3}$. The prepared $\mathrm{WO}_{3}-\mathrm{Tr}$ and $\mathrm{WO}_{3}-\mathrm{Cys}$ exhibited strong dye removal activity toward methylene blue and safranin dyes with complete dye removal $(100 \%)$ after $6 \mathrm{~h}$. $\mathrm{WO}_{3}$-Cys and $\mathrm{WO}_{3}$-Trp $\mathrm{NPs}$ revealed higher broad-spectrum antibacterial activity toward both Gram-negative and Gram-positive bacteria, with strong antifungal activity toward Candida albicans. Anticancer results of the modified $\mathrm{WO}_{3}-\mathrm{Cys}$ and $\mathrm{WO}_{3}-\mathrm{Trp} \mathrm{NPs}$ against various kinds of cancer cells, including MCF-7, Caco-2, and HepG-2 cells, indicate that they have a potent effect in a dose-dependent manner with high selectivity to cancer cells and safety against normal cells. The expression levels of E2F2 and Bcl-2 genes were found to be suppressed after treatment with both $\mathrm{WO}_{3}$-Cys and $\mathrm{WO}_{3}$-Trp NPs more than 5-FU-treated cells. While expression level of the p53 gene in all tested cells was up-regulated after treatment 5-8 folds more as compared to untreated cells. The docking results confirmed the ability of both NPs to bind to the p53 gene with relevant potency in binding to other tested gens and participation of cysteine SH-functional group in such interaction.
\end{abstract}

Keywords: modified nanocombinations; L-tryptophan and L-cysteine; antimicrobial; anticancer

\section{Introduction}

Tungsten oxide $\left(\mathrm{WO}_{3}\right)$ is considered as one of the most promising transition metal oxides, for their performance in various applications, including electrochromic devices $[1,2]$, dye-sensitized solar cells [3,4], photocatalytic applications [5], sensing applications [6,7], field-emission applications [8], high-temperature superconductors [9], optical recording devices [10], and adsorbent [11]. The wide application for $\mathrm{WO}_{3}$ could be attributed to its high chemical stability and remarkable electric conductivity in addition to the ability in the reverse-redox process [12]. Moreover, tungsten oxide could be prepared in different morphological structures, including nanorods [13], nanotubes [14], nanosheets [7], nanowires [15], and nanobelts [16]. Several techniques were investigated for the preparation of $\mathrm{WO}_{3}$ using either physical or chemical approaches; thermal evaporation [17], spray 
pyrolysis [18], sol-gels [19], the templating method [20], hydrothermal [13], electrochemical anodization [21], electrodeposition [12], and the microwave-assisted method [5].However, these methods are time-consuming, and relatively complicated processes with a limitation in controlling the size and shape of the resulted nanoparticles [5,22]. One of the simplest and cost-effective methods for preparing tungsten trioxide nanoparticles is acid precipitation [23]. Great attention has recently been directed toward increasing the nanometals implementation in various industrial sectors attributed to its tiny size and large surface-tomass ratio, besides its remarkable stability in many harsh conditions [24,25]. Nonetheless, the high biotoxicity of some well-known NPs $(\mathrm{Ag}, \mathrm{Cu}$, Ti, etc.) has restricted their wide commercial usage [26,27]. To overcome the toxicity issue, attention was directed toward NPoxides as a safer and effective alternative [28]. In the same regard, NPs surface modification was also proposed to increase the NPs applicability range with lower side toxicity $[29,30]$. Recently, growing interest in nanoparticles surface functionalization with different functional groups and bio-macules as amino acids, short peptides, and proteins toward new applications has been intensively reported $[29,31]$. Owing to the large surface-to-mass ratio, NPs adsorb these biomolecules on their large surface area in corona-like structure through Van der Waals forces, revealing new biological activities [32].

Nowadays, surface-functionalized NPs are efficiently applied in many fields, including environmental and medical fields. With growing dye-dependent industries, synthetic dye effluents represent great environmental and public health challenges attributed to their significant toxicity [25,33-35]. Though many approaches were proposed for dye remediation [33], the lower efficiency and high cost involved limiting their commercial applications [36]. Biotechnological applications of various NPs in hazardous chemicals remediation is an emerging field [25], with advantages of surface modification that enhance their dye-removal capacity [37]. Cancer has recently been considered as a global health threat representing the world's second leading cause of death, with the expectation of becoming the leading cause of death in future years [38,39]. Cancer treatment, through the currently available protocols, usually results in immunosuppression for treated patients, a condition that renders them at high risk for severe microbial infections [40]. Developing a new anticancer agent with consolidated antimicrobial activity is a pressing need. To this end, inorganic nanometals represent one step forward, with their high antitumor and antimicrobial activity with minor bacterial-resistance evolution ability [41]. Moreover, the high stability of NPs toward harsh conditions, including temperature and $\mathrm{pH}$ intensifies the efforts for its successful medical applications [42]. Short peptides and amino acids have also attracted attention as promising antimicrobial agents [43]. Currently, there is wide interest in individual amino acid (AA) interaction with different NPs for better understanding and elucidation of corona-like structures and to give a deeper insight into the new resulting biological activities $[44,45]$. Cysteine and tryptophan-rich short peptides have revealed potent antimicrobial activity against many human pathogens [46,47]. The current study concerns the preparation and functionalization of $\mathrm{WO}_{3} \mathrm{NPs}$ with tryptophan or cysteine amino acids and evaluates the efficacy of the resulting NPs-AAs in versatile applications, including synthetic dye removal, antimicrobial, and antitumor activities.

\section{Material and Methods}

\subsection{Preparation of $\mathrm{WO}_{3} \mathrm{NPS}$}

The $\mathrm{WO}_{3}$ NPs were prepared by passing $10 \mathrm{~mL}(0.5 \mathrm{M})$ of $\mathrm{Na}_{2} \mathrm{WO}_{4}(>98 \%$, SigmaAldrich, Taufkirchen, Germany) solution through Ion exchanger Dowex ${ }^{\circledR} 50$ WX 4 (strongly acidic cation exchanger), $\mathrm{H}^{+}$form, (obtained from Merck, Darmstadt, Germany) packed column. The yielded yellow solution was collected from the column in a blue-capped bottle at a flow rate of $10 \mathrm{~mL} / \mathrm{min}$ using phosphate buffer saline (PBS, $\mathrm{pH}$ 7.2). Thereafter, the bottle was placed in an oven at $50{ }^{\circ} \mathrm{C}$ for $24 \mathrm{~h}$ (Figure 1A). The produced precipitate was separated by filtration, washed several times with double distilled water $\left(\mathrm{ddH}_{2} \mathrm{O}\right)$, dried at $70{ }^{\circ} \mathrm{C}$, and finally, stored in a dark bottle for further use. 

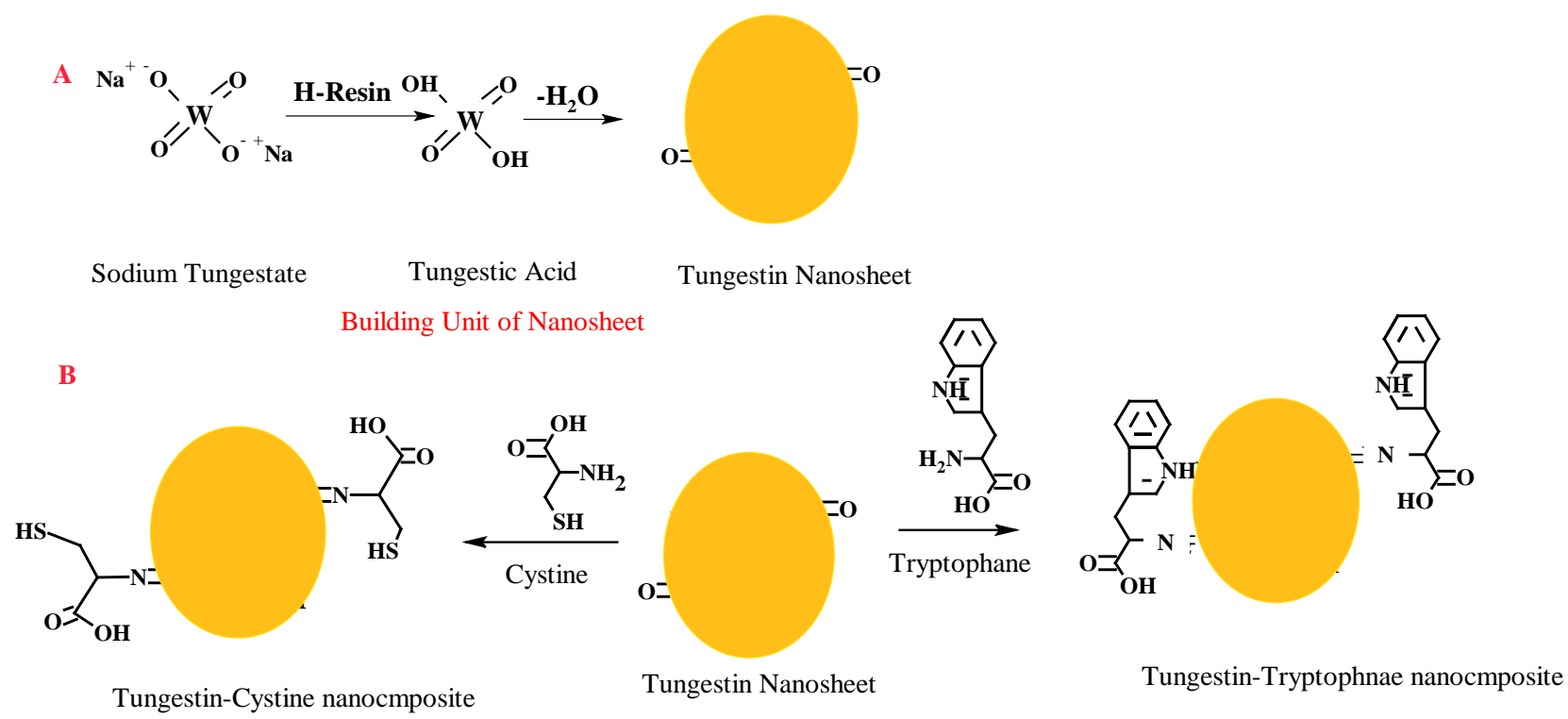

Figure 1. Preparation of $\mathrm{WO}_{3} \mathrm{NPs}$ through cation resin (A) and interaction of the prepared $\mathrm{WO}_{3} \mathrm{NPs}_{\text {sith amino acids }}$ L-tryptophan or L-cysteine (B).

\subsection{Surface Functionalization of $\mathrm{WO}_{3} \mathrm{NPs}$ with Tryptophan or Cysteine}

Surface functionalization of the prepared $\mathrm{WO}_{3}$ was conducted through mixing equal volumes of the prepared $\mathrm{WO}_{3} \mathrm{NPs}(0.2 \mathrm{mg} / \mathrm{mL})$ with tryptophan or cysteine $(0.05 \mathrm{mg} / \mathrm{mL})$ in $0.1 \mathrm{M}$ phosphate $\mathrm{pH} 7.0$ with stirring for $6 \mathrm{~h}$. The mixtures were then centrifuged to eliminate the unbound amino acids, and washed several times with $\mathrm{ddH}_{2} \mathrm{O}$ and PBS, $\mathrm{pH}$ 7.2. Finally, the resulting NP-AA pellets were used during the following experiments (Figure 1B).

\subsection{Characterizations of $\mathrm{WO}_{3} \mathrm{NPs}$ and Surface-Functionalized $\mathrm{WO}_{3}$-AAs}

The pristine $\mathrm{WO}_{3}$ and surface functionalized $\mathrm{WO}_{3}$-AAs were characterized using scanning electron microscopy (SEM; JSM 6360LA, Tokyo, Japan), Fourier transform-infrared (FT-IR) analysis using Shimadzu FTIR (Model, FTIR8400, Kyoto, Japan), thermal gravimetric analysis (TGA; Shimadzu Thermal Gravimetric Analysis, Kyoto, Japan), and the elemental EDS unit related to SEM.

\subsection{Application of $\mathrm{WO}_{3} \mathrm{NPs}$ and Functionalized $\mathrm{WO}_{3}-\mathrm{AAs}$ in Synthetic Dyes Removal}

The ability of the modified $\mathrm{WO}_{3}$-AAs in synthetic dyes remediation was evaluated against some synthetic dye solutions and compared to plain $\mathrm{WO}_{3} \mathrm{NPs}$ and separate amino acids. Dye solutions (100 ppm/final conc.) were prepared by dissolving methylene blue and safranin in $0.1 \mathrm{M}$ phosphate buffer, $\mathrm{pH}$ 7.0. Dye decolorization test was performed at a final volume of $5.0 \mathrm{~mL}$ by separately adding $0.4 \mathrm{mg} / \mathrm{mL}$ of $\mathrm{NPs}, \mathrm{WO}_{3}$-AAs, or AAs to each dye solution. The reaction mixtures were incubated at room temperature for $6 \mathrm{~h}$. Samples were withdrawn from each tube every $1 \mathrm{~h}$ and measured using a UV-vis spectrophotometer at wavelengths of $662 \mathrm{~nm}$ and $495 \mathrm{~nm}$ for methylene blue and safranin, respectively.

\subsection{Antimicrobial Efficacy of the Surface-Functionalized $\mathrm{WO}_{3}-A A \mathrm{NPS}$}

The antimicrobial activity of the prepared $\mathrm{WO}_{3}$-AA NPs was investigated against three pathogenic strains, including Staphylococcus aureus (ATCC 25923), Pseudomonas aeruginosa (ATCC 27853), and Candida albicans (ATCC 10231) along with plain $\mathrm{WO}_{3}$ and separate AAs as controls. Microplate reader assay was applied in this test, where pre-culture was prepared by overnight cultivation of the three organisms on nutrient broth medium at $37^{\circ} \mathrm{C}$. Tissue culture plates (flat-bottom 96 wells) were inoculated separately with $100 \mu \mathrm{L}$ of the diluted tested organism $(106 \mathrm{CFU} / \mathrm{mL})$ and serially diluted compounds $(5-80 \mu \mathrm{g})$ to a final 
volume of $200 \mu \mathrm{L}$. The microtiter plates were incubated overnight at $37^{\circ} \mathrm{C}$ and measured at $600 \mathrm{~nm}$ with a microplate reader. Antimicrobial results were expressed as minimum inhibitory concentration (MIC), defined as the lowest concentration that eliminated all cells.

\subsection{In Vitro Anticancer Studies}

\subsubsection{Cell Culture and Media}

Human normal amnion (WISH), human cells derived from breast adenocarcinoma (MCF-7), human epithelial cells derived from colorectal adenocarcinoma (Caco-2), and human hepatocyte carcinoma (HepG-2) cell lines were obtained from VACSERA (Cairo, Egypt). DMEM and RPMI-1640 media were obtained from Lonza (Lmd. Co., Basel, Switzerland). Human WISH and Caco-2 cell lines were cultured in DMEM media supplemented with 10\% FBS (Fetal bovine serum). However, MCF-7 and HepG-2 cell lines were cultured in RPMI-1640 media supplemented with 10\% FBS.

\subsubsection{Cytotoxicity Evaluation Using MTT Assay}

The anticancer effect of the functionalized $\mathrm{WO}_{3}$-AAs NPs was evaluated through MTT (3-[4,5-Dimethylthiazol]-2,5-Diphenyltetrazolium bromide) assay protocol using normal and cancerous cells as described previously by El-Fakharany et al. [48]. Briefly, both normal and cancer cells $\left(1.0 \times 10^{4}\right.$ /well $)$ were seeded in four sterile 96-well microplates and incubated for $24 \mathrm{~h}$ with complete culture media. Serially diluted functionalized $\mathrm{WO}_{3}-\mathrm{AAs}$ NPs at concentrations of $0.1-0.5 \mathrm{mg} / \mathrm{mL}$ were added to the cultured cells in triplicates and incubated for $48 \mathrm{~h}$ in a $5 \% \mathrm{CO}_{2}$ incubator. Then, cells were washed 3 times with fresh media, and $200 \mu \mathrm{L}$ of MTT solution $(0.5 \mathrm{mg} / \mathrm{mL})$ was added to each well for $3-5 \mathrm{~h}$. After the incubation period, MTT solution was substituted with $200 \mu \mathrm{L}$ of DMSO for dissolving formazan crystals. The optical density was measured at $590 \mathrm{~nm}$ using a microplate reader. The $\mathrm{IC}_{50}$ value (half maximal inhibitory concentration) of each $\mathrm{WO}_{3}$-AAs NPs that cause killing of 50\% cells was determined by the Graphpad Instate software 6.0 and values of selectivity index (SI) which defined as the ratio of $\mathrm{IC}_{50}$ of normal cells versus cancer cells were also estimated as described previously by Abu-Serie and El-Fakharany [49].

\subsubsection{Nuclear Staining}

The anticancer and apoptotic effect of the $\mathrm{WO}_{3}-\mathrm{Cys}$ and $\mathrm{WO}_{3}-\operatorname{Tr} \mathrm{NPs}$ against HepG-2 cells was studied by fluorescent nuclear stain method using propidium iodide (PI) dye in comparison with untreated reference cells. HepG-2 cells were incubated in triplicate and treated with different NPs at different concentrations of $0.1,0.2$, and $0.3 \mathrm{mg} / \mathrm{mL}$, as described above. Both untreated and treated cells were washed 3 times with fresh media for removing debris and dead cells and then fixed with $4 \%$ paraformaldehyde for $10 \mathrm{~min}$ at room temperature. After the fixing step, permeabilization of the cells with $0.5 \%$ Triton X-100 and 3\% paraformaldehyde was performed for $1 \mathrm{~min}$. The PI dye at a concentration of $10 \mu \mathrm{g} / \mathrm{mL}$ was added to stain the cells for $20 \mathrm{~min}$. The cells were examined and imaged by a fluorescence phase-contrast microscope (Olympus, Tokyo, Japan) using an excitation filter of $480 / 30 \mathrm{~nm}$ [50].

\subsubsection{Effect of the Surface-Functionalized $\mathrm{WO}_{3}-\mathrm{AA}$ NPs on Gene Expression}

The effect of the prepared $\mathrm{WO}_{3}$ and surface-functionalized $\mathrm{WO}_{3}-\mathrm{AA} \mathrm{NPs}$ on the expression level of some tumor genes, including transcription factor 2 gene (E2F2), tumor suppressor gene (p53), and oncogene (Bcl-2) was determined in human MCF-7, Caco2, and HepG-2 cells using qPCR method according to the manufacturer's instructions for the SYBR green kit (BiotechCo., Ltd., Carrollton, TX, USA). After treatment, the cancer cells with the modified $\mathrm{WO}_{3}-\mathrm{Cys}$ and $\mathrm{WO}_{3}-\mathrm{Tr} \mathrm{NPs}$ at $\mathrm{IC}_{50}$ concentrations for each modified NP as described above, total RNAs of each untreated and treated cancer cell line were extracted using the protocol of Gene JET RNA Purification Kit (Thermo Scientific, Waltham, MA, USA). Real-time PCR of each cDNA was carried out by a master mix of SYBR green kit using specific primers (Forward/Reverse) as follows: $5^{\prime}$ - 
GCATCCAGTGGAAGGGTGTG-3' $/ 5^{\prime}$-ACGTTCCGGATGCTCTGCT-3' for E2F2 gene, $5^{\prime}$ TAACAGTTCCTGCATGGGCGGC-3' $/ 5^{\prime}$-AGGACAGGCACAAACACGCACC-3' for p53 gene, and $5^{\prime}$-TCCGATCAGGAAGGCTAGAGTT- $3^{\prime} / 5^{\prime}$-TCGGTCTCCTAAAAGCAGGC- $3^{\prime}$ for Bcl-2 gene. The change of the gene expression level for each cell line before and after treatment was determined by using the equation of $2^{-\Delta \Delta C T}\left(2^{\wedge}(-\right.$ delta delta of the threshold cycles $(C T s))$.

\subsection{Docking Studies}

Molecular docking studies were carried out for simulating the interaction of $\mathrm{WO}_{3}$ $\mathrm{NPs}$ and $\mathrm{WO}_{3}$-AAs into three important cancer developing proteins, namely, Bcl-2, p53, and E2F2. The crystal structures of the three aforementioned proteins were downloaded from the protein data bank (PDB) website with ID 2W3L, 3ZME, and 5TUU, respectively. Molecular operating environment (MOE) software was used to conduct molecular docking. The downloaded protein was prepared by 3D protonation, deletion of water molecules and unwanted peptide chains, and energy minimization. The pocket was obtained by isolating the molecular surface around the binding site (within $4.5 \AA$ A near the ligand atom). Validation was carried out by redocking the crystallized ligand. Rigid protocol docking (default protocol) was selected. The docking protocol is considered valid when the root mean square deviation (RMSD) of the docking pose compared to the co-crystal ligand position is about $1.5 \AA$ or less. To prepare $\mathrm{WO}_{3} \mathrm{NPs}$ and modified $\mathrm{WO}_{3}$-AAs for docking, the structure of the studied compound was built on MOE. 3D protonation was selected, then energy minimization (force field: MMFF94x) was applied. The prepared compounds were added to the created database, which was then selected for docking according to the default protocol in which the bond rotation method generated ligand conformations. The conformers are placed on the site with the Triangle matcher method [51].

\subsection{Statistical Analysis}

All data were expressed as mean $\pm \mathrm{SE}$ (standard error of the mean) of three different experiment measurements. The statistical significance was assessed by the multiple comparisons of Tukey's post-hoc analysis of variance (ANOVA) using the SPSS16 program (IBM, Armonk, NY, USA). Differences of the results were considered statistically significant at $(p)$-values $<0.05$.

\section{Results and Discussions}

\subsection{Characterization of $\mathrm{WO}_{3} \mathrm{NPs}$ and $\mathrm{WO}_{3}$-Amino Acid ( $\mathrm{WO}_{3}$-AAs) Complexes}

The $\mathrm{WO}_{3} \mathrm{NPs}$ were prepared from $\mathrm{Na}_{2} \mathrm{WO}_{4}$ solution eluted through a strong cation exchange resin where the resulted yellow solution was precipitated and dried at $70{ }^{\circ} \mathrm{C}$. The surface of dried NPs was functionalized with Trp or Cys (Figure 1). Moreover, Figure 1 revealed that each building unit of the WO3 nanosheet contains two terminal (W = Ot) groups, which were available to interact with two amino acid units through the amine group. Therefore, we suggested that the molecular ratio between $\mathrm{WO}_{3}$ nanosheet and amino acids was 1:2. The appearance of synthesized $\mathrm{WO}_{3} \cdot \mathrm{H}_{2} \mathrm{O}$ and modified $\mathrm{WO}_{3}$-AAs at various magnifications was explored by SEM (Figure 2). The SEM photos presented $\mathrm{WO}_{3} \cdot \mathrm{H}_{2} \mathrm{O}$ in separated nanosheet morphology with a homogeneous size and dimensions determined to be about $0.14 \mu \mathrm{m}$ in average thickness and $0.33-0.74 \mu \mathrm{m}$ length/width using software of the SEM-Smile View program (Figure 2). The functionalized $\mathrm{WO}_{3}-\mathrm{AAs}$ complexes under the SEM microscope presented as a coagulated structure formed from the $\mathrm{WO}_{3} \cdot \mathrm{H}_{2} \mathrm{O}$ sheets linked with each other by the amino acid to form agglomerated $\mathrm{WO}_{3} \cdot \mathrm{H}_{2} \mathrm{O}$ nanosheets / AAs complexes (Figure 2). In a related work, individual amino acids, especially for histidine, were proposed for better understanding the NPs and protein interaction [52]. Though several mechanisms have been proposed for the interaction of protein and amino acids on the surface of NPs, the exact mechanism is not fully understood [30]. As per the literature, the corona-like structure resulting from the proteins and NPs interaction is a well-established theory for elucidating the different biological behaviors of NPs in 
the biological media $[52,53]$. It is worth mentioning that the $\mathrm{WO}_{3} \cdot \mathrm{H}_{2} \mathrm{O}$ keeps on its sheet morphology in the resulting $\mathrm{WO}_{3}$-AAs complexes.
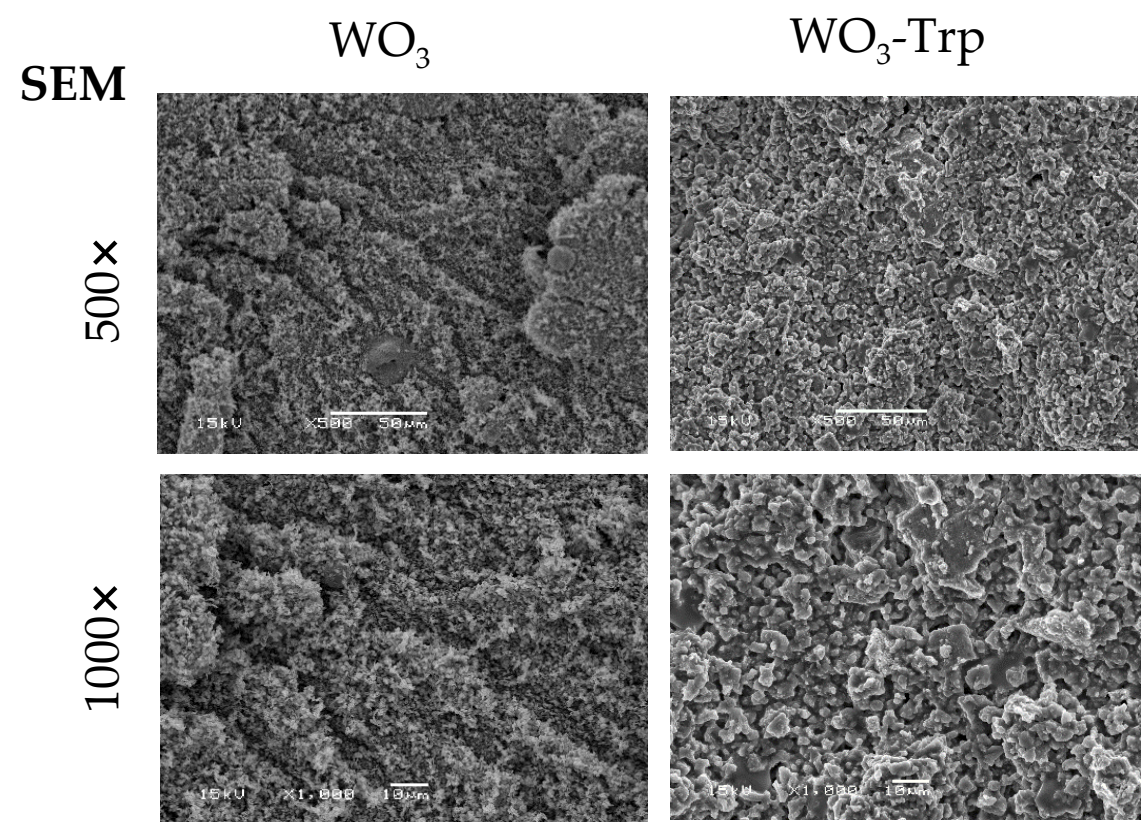

$\mathrm{WO}_{3}-\operatorname{Trp}$
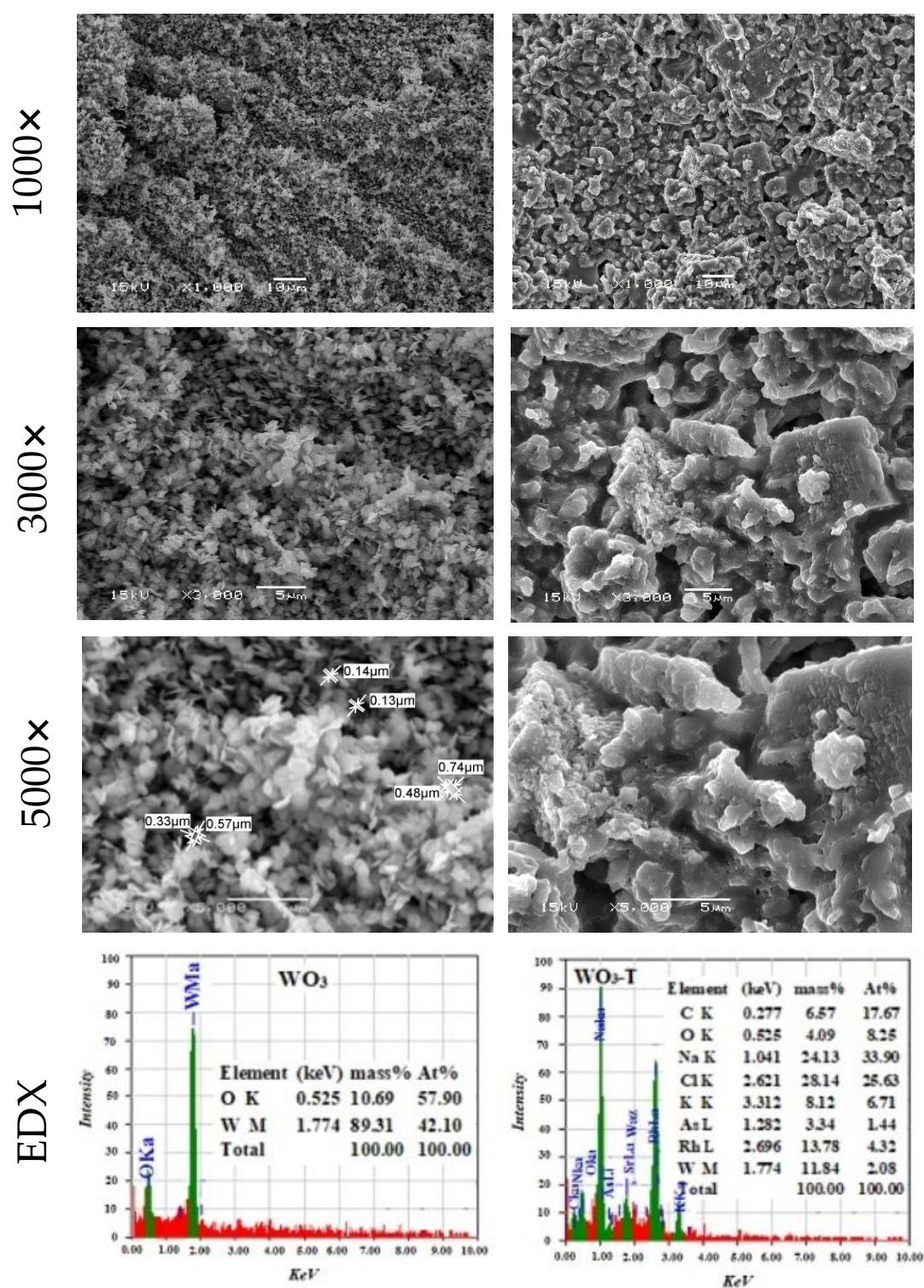
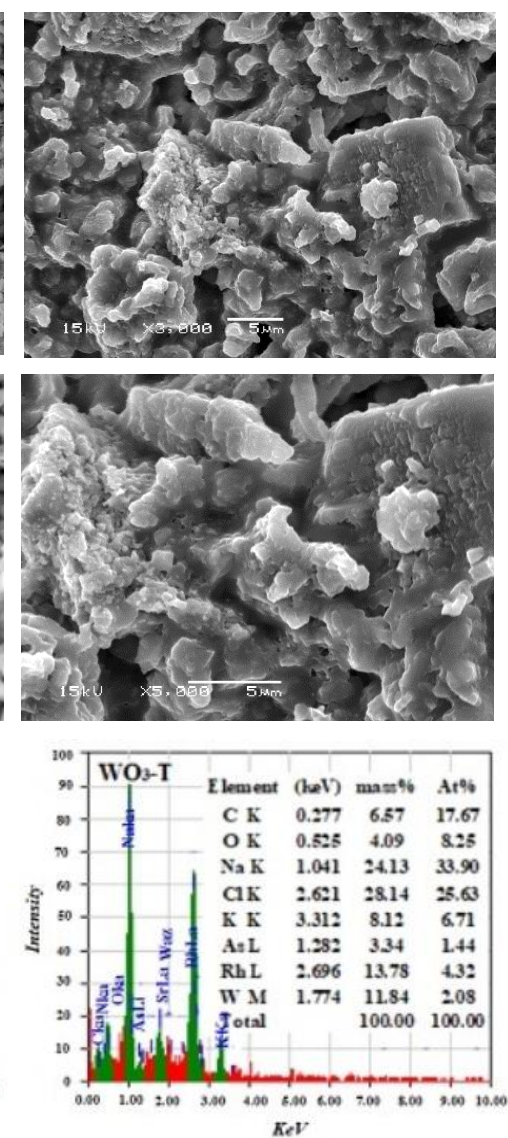

$\mathrm{WO}_{3}$-Cys
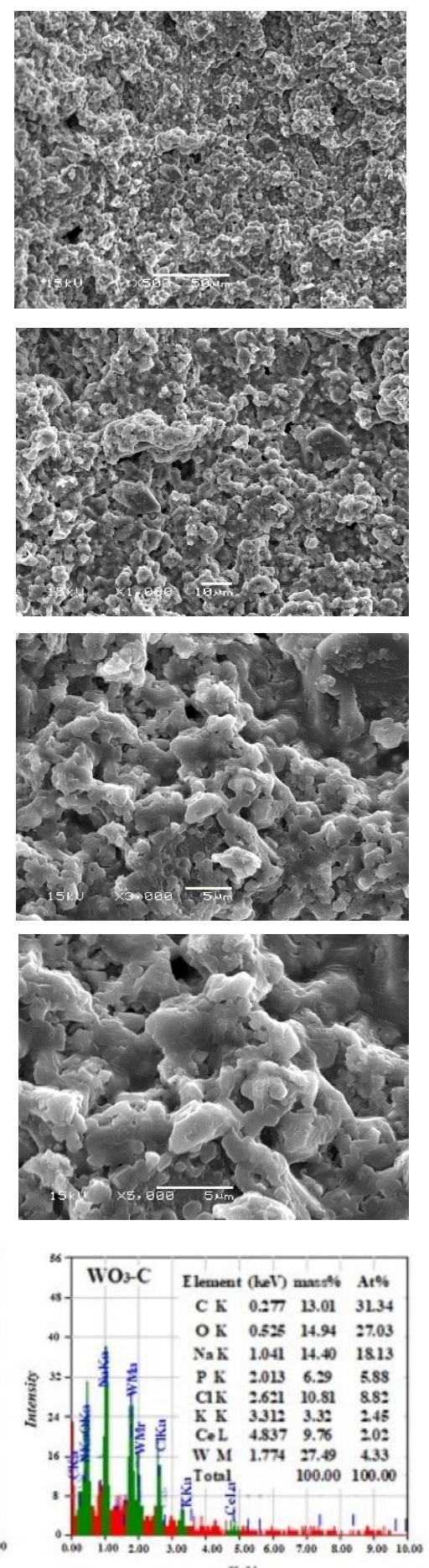

$\mathrm{KeV}$

Figure 2. SEM and EDX analysis for prepared $\mathrm{WO}_{3} \mathrm{NPs}$ (column 1), $\mathrm{WO}_{3}$-Trp (column 2) and $\mathrm{WO}_{3}$-Cys (column 3) at different magnifications (Element: $\mathrm{W}, \mathrm{O}, \mathrm{C}, \mathrm{Na}, \mathrm{Cl}, \mathrm{K}, \mathrm{As}, \mathrm{Rh}, \mathrm{P}, \mathrm{Ce}$; Shell: $\mathrm{K}, \mathrm{L}, \mathrm{M}$; Mass\%: Mass percent of the element in the materials; At $\%$ : Atomic percent of the element in the materials).

Energy-dispersive X-ray spectroscopy (EDS) was applied to reveal the elemental analysis of the materials. The analysis demonstrated that the synthesized $\mathrm{WO}_{3} \cdot \mathrm{H}_{2} \mathrm{O}$ is 
free from impurities, where powder is composed of \%At $(\mathrm{W}=42.10$ and $\mathrm{O}=57.90)$ as shown in Figure 2. On the other hand, EDS examination of the surface-functionalized $\mathrm{WO}_{3}$ $\left(\mathrm{WO}_{3}-\mathrm{Trp}\right.$ and $\left.\mathrm{WO}_{3}-\mathrm{Cys}\right)$ revealed the presence of carbon atoms (Figure 2), indicating that the carbons came from the two amino acids.

The FT-IR spectra were used to identify the structural-functional groups of $\mathrm{WO}_{3} \cdot \mathrm{H}_{2} \mathrm{O}$ and $\mathrm{WO}_{3}$-AAs complexes (Figure 3A). The IR spectrum of $\mathrm{WO}_{3} \cdot \mathrm{H}_{2} \mathrm{O}$ (Figure $3 \mathrm{~A}$ ) revealed a broad band at $3387 \mathrm{~cm}^{-1}$ corresponding to the stretching motion of $\mathrm{O}-\mathrm{H}$, the band at $1624 \mathrm{~cm}^{-1}$ is due to in-plane bending $\delta(\mathrm{H}-\mathrm{O}-\mathrm{H})$ of the water molecule. Moreover, the weak band at $938 \mathrm{~cm}^{-1}$ characterized the stretching of $\mathrm{W}=\mathrm{O}_{\mathrm{t}}$ (where $\mathrm{O}_{\mathrm{t}}$ is the terminal oxygen). The intense sharp band at $666 \mathrm{~cm}^{-1}$ revealed the stretching of $\mathrm{W}-\mathrm{O}$. Upon reacting with Trp or Cys, the peaks related to the stretching motion of $\mathrm{O}-\mathrm{H}$ become more intense, broader, and shifted to 3428 and 3442, respectively (Figure 3A). Furthermore, the bending $\delta(\mathrm{H}-\mathrm{O}-\mathrm{H})$ of the water molecule band becomes more intense and shifted to $1650 \mathrm{~cm}^{-1}$ with Trp and to $1644 \mathrm{~cm}^{-1}$ in the case of Cys. The results (Figure 3A,B) revealed several new bands at 1434, $1272,1115,1063,984,888,627,525 \mathrm{~cm}^{-1}$ for $\mathrm{WO}_{3}-\operatorname{Trp}$ complex and 1423, 1272, 1114, 1061, $983,888,654,532 \mathrm{~cm}^{-1}$ for $\mathrm{WO}_{3}-$ Cys complex where the intense sharp band at $666 \mathrm{~m}^{-1}$ disappears (Figure 3 ). These results asserted the successful interaction between the two amino acids and $\mathrm{WO}_{3} \mathrm{NPs}$.
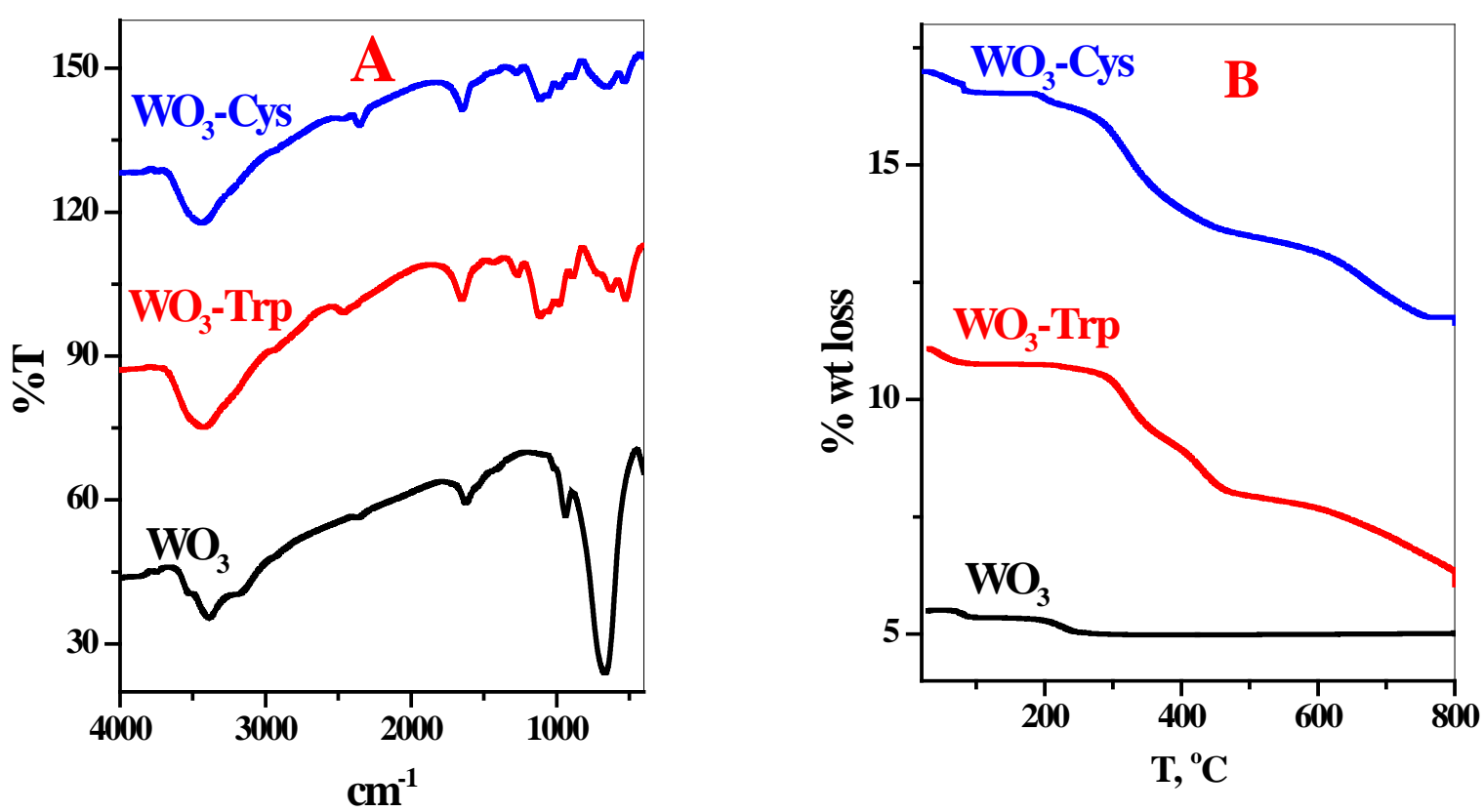

Figure 3. FT-IR spectroscopy (A) and TGA analysis (B) for the prepared $\mathrm{WO}_{3} \mathrm{NPs}$ with $\mathrm{WO}_{3}$-Trp and $\mathrm{WO}_{3}$-Cys modified $\mathrm{NPs}$.

The thermal stability of $\mathrm{WO}_{3} \cdot \mathrm{H}_{2} \mathrm{O}$ and $\mathrm{WO}_{3}$-AAs complexes was tested using TGA analysis, as seen in Figure 3B. The $\mathrm{WO}_{3} \cdot \mathrm{H}_{2} \mathrm{O}$ present two main decomposition stages $64-90{ }^{\circ} \mathrm{C}(2.5 \%)$ related to the evaporation of adsorbed water $197-249{ }^{\circ} \mathrm{C}(4.5 \%)$ corresponding to the release of intermolecular water (Figure 3B). Attributed to modification of the $\mathrm{WO}_{3} \mathrm{NPs}$ with tryptophan $\left(\mathrm{WO}_{3}-\mathrm{Trp}\right)$ or cysteine $\left(\mathrm{WO}_{3}-\mathrm{Cys}\right)$, the TGA properties of the produced composites were consequently altered from the original $\mathrm{WO}_{3}$ (Figure 3B). For both composites, desorption of solvent, physically bonded water, and surface hydroxyl groups were assessed through the loss in the mass in the region below $200{ }^{\circ} \mathrm{C}$. At temperature $\geq 250{ }^{\circ} \mathrm{C}$, the two composites presented smoothly and decreased in their masses. This is related to the degradation of the organic materials on the substrate of $\mathrm{WO}_{3}$ NPs (Figure 3B). This decomposition behavior presented suitable thermal stability for the organic modifier, confirming the interaction and linking of the amino acids to the surface of $\mathrm{WO}_{3}$ NPs. 


\subsection{Dye Decolorization Activity of Prepared $W_{3}$ and Modified $W_{3}-A A s ~ N P s$}

The ability of modified $\mathrm{WO}_{3}$-Trp and $\mathrm{WO}_{3}$-Cys NPs toward synthetic dye remediation was evaluated against some synthetic dye solutions (100 ppm/final conc.) and compared to plain $\mathrm{WO}_{3} \mathrm{NPs}$ and separate AAs. Among the tested dye solutions, $\mathrm{WO}_{3}-\mathrm{AAs}$ revealed high dye removal capacity against methylene blue and safranin dyes (Figure 4) compared to $\mathrm{WO}_{3} \mathrm{NPs}$ and separate AAs. The decolorization rate of the two dyes was further studied by following up dye decolorization for $6 \mathrm{~h}$, where samples were withdrawn and measured using a UV-visible spectrophotometer with $1 \mathrm{~h}$ interval (Figure 4). The results indicate great enhancement in the dye removal capacity for $\mathrm{WO}_{3}$-Trp and $\mathrm{WO}_{3}$-Cys modified NPs toward methylene blue and safranin dyes with complete dye removal (100\%) after $6 \mathrm{~h}$ compared to plain $\mathrm{WO}_{3}$ that revealed moderate activity with 47 and $70 \%$ of dye decolorization for methylene blue safranin, respectively. In solutions, cationic dyes particles (as methylene blue and safranin) usually aggregate on the large negatively charged surface of the $\mathrm{WO}_{3} \mathrm{NP}$. When cationic dyes are available in high concentration, more dye particles are adsorbed to the $\mathrm{WO}_{3} \mathrm{NP}$ surface, which increases their density and the $\mathrm{WO}_{3}$-dyes aggregate perception started [54]. The amino acids (Trp and Cys) on the modified $\mathrm{WO}_{3} \mathrm{NP}$ may enhance the first step of dye-NP aggregation through their abundant $\mathrm{COO}^{-}$groups that bind strongly to the positively charged dye particles, revealing higher dye removal activity compared to the original $\mathrm{WO}_{3} \mathrm{NP}$. The surface modification of $\mathrm{WO}_{3} \mathrm{NP}$ was reported to enhance its dye removal activity [55]. Dinari and his colleagues reported enhancement in methylene blue dye removal by a photocatalytic modified multi-walled carbon nanotube $/ \mathrm{WO}_{3}$ compared to $\mathrm{WO}_{3} \mathrm{NP}$ [56]. The two separate AAs revealed no detectable decolorization activity toward both dye solutions (Figure 4). Though the decolorization rate of $\mathrm{WO}_{3}$-Trp for both dyes was faster than $\mathrm{WO}_{3}-\mathrm{Cys}$, the time required for complete degradation of methylene blue and safranin dyes was the same $(6 \mathrm{~h})$.
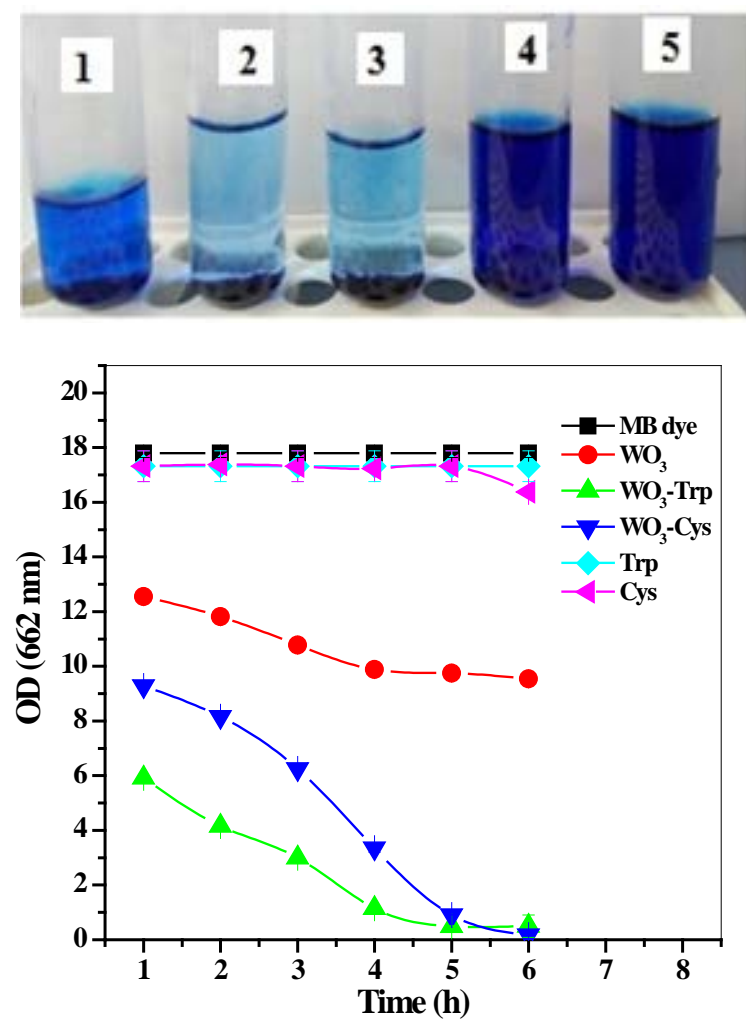

II
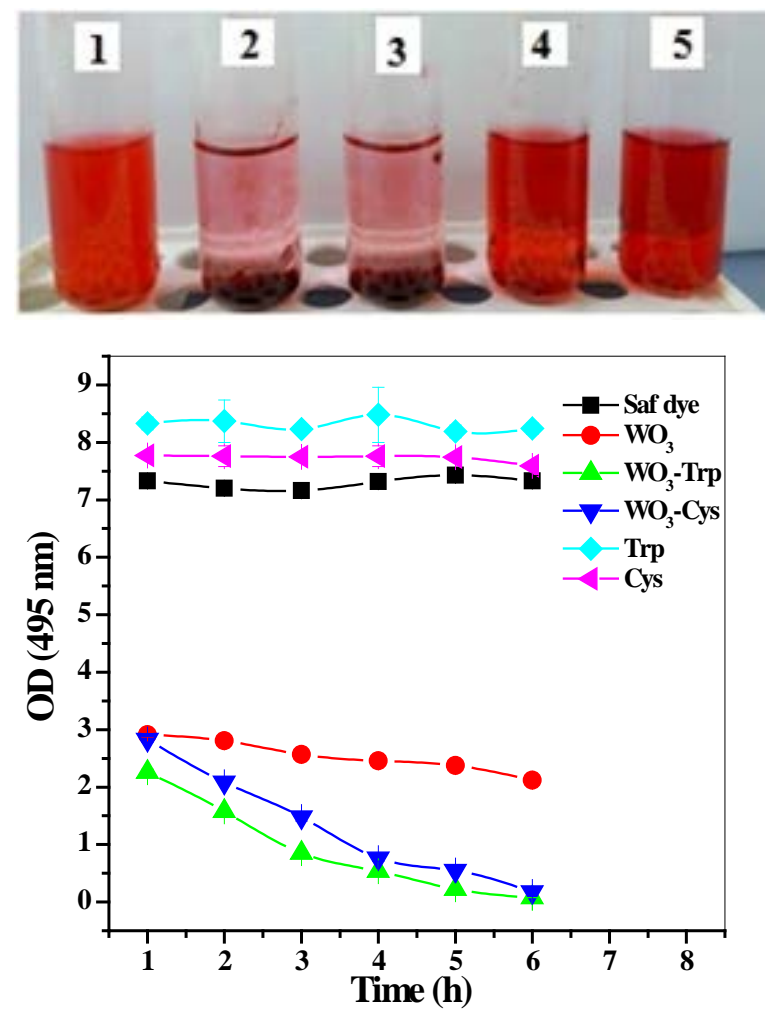

Figure 4. Photographs (A) and decolorization percentages (B) of dye removal rate for methylene blue (I) and safranin (II) by the prepared modified $\mathrm{WO}_{3}$ NPs with Trp and Cys. Methylene blue and safranin at a concentration of $100 \mathrm{mg} / \mathrm{mL}$ were decolorized by $\mathrm{WO}_{3} \mathrm{NPs}(1)$, the modified $\mathrm{WO}_{3}-\operatorname{Tr} \mathrm{p}(2), \mathrm{WO}_{3}-\mathrm{Cys}(3)$, Trp (4), and Cys (5) for $6 \mathrm{~h}$. The data are presented as mean \pm SE and represent the average values from three experiments $(n=3)$. 


\subsection{Antimicrobial Activity of Prepared NPs and Modified Amino Acid-NPs}

The widespread microbial pathogens for multi-resistance implies a necessity for efficient broad-spectrum antimicrobial molecules with lower microbial resistance induction capacity. Antimicrobial activity of the $\mathrm{WO}_{3}$-AAs NPs was investigated against three pathogenic strains, including Staphylococcus aureus (ATCC25923), Pseudomonas aeruginosa (ATCC 27853), and Candida albicans (ATCC 10231) along with plain $\mathrm{WO}_{3}$ and AAs as controls (Table 1). The results (Table 1 ) showed that pure $\mathrm{WO}_{3}$ showed no antimicrobial activity against the applied pathogens, which, consistent with other's findings [55], reported the inability of pure $\mathrm{WO}_{3}$ to inactivate pathogenic bacterial cells even after under visible light illumination for $6 \mathrm{~h}$. Separate Cys and Trp revealed considerable antimicrobial activity compared to that of Trp and $\mathrm{WO}_{3} \mathrm{NPs}$. The results also indicate a synergistic enhancement in the antimicrobial activity of $\mathrm{WO}_{3} \mathrm{NPs}$ via modification with the applied amino acids as $\mathrm{WO}_{3}$-Cys revealed higher broad-spectrum antibacterial activity toward Staphylococcus aureus and Pseudomonas aeruginosa compared to MIC values of Cys $(85.82$ and $112.7 \mu \mathrm{g} / \mathrm{mL})$, with limited antifungal activity toward Candida albicans $(105.9 \mu \mathrm{g} / \mathrm{mL})$ compared to that of Cys $(115 \mu \mathrm{g} / \mathrm{mL})$. The results, consistent with other's findings, stated the potency of Cys and Cys-rich peptides as promising antibacterial agents [46,57]. Recently, short peptides and amino acid-rich biomolecules rise as promising bacteriostatic agents that most likely target outer bacterial membrane rather than intracellular bacterial structures $[46,58]$. The thiol side chain in cysteine is highly reactive and hypothetically initiates the first interaction toward bacterial cell membranes $[46,59]$. On the other hand, $\mathrm{WO}_{3}$-Trp also revealed broad-spectrum antibacterial activity toward Staphylococcus aureus (MIC $72.5 \mu \mathrm{g} / \mathrm{mL}$ ) and Pseudomonas aeruginosa (MIC $104.7 \mu \mathrm{g} / \mathrm{mL}$ ) with strong antifungal activity toward Candida albicans $(42.8 \mu \mathrm{g} / \mathrm{mL})$. The role of Trp as a hydrophobic AAs in antimicrobial-peptides was asserted $[47,60]$ through initiating the first and strong anchoring to the bacterial membrane and affect the interface region of lipid bilayer leading to cell membrane destruction.

Table 1. The antimicrobial activity (MIC values) of the modified $\mathrm{WO}_{3}-\mathrm{Cys}$ and $\mathrm{WO}_{3}$-Trp $\mathrm{NPs}$ against three pathogenic microorganisms in comparison with $\mathrm{WO}_{3} \mathrm{NPs}$ and free amino acids (Cys and Trp).

\begin{tabular}{cccccc}
\hline Test Organism & $\mathbf{W O}_{3}$ & $\mathbf{W O}_{3}$-Trp & $\mathbf{W O}_{3}$-Cys & Trp & Cys \\
\hline Staphylococcus aureus & 452.90 & 72.53 & 53.14 & 454.00 & 85.82 \\
\hline Pseudomonas aeruginosa & 307.70 & 104.70 & 60.52 & 199.50 & 112.70 \\
\hline Candida albicans & 324.90 & 42.81 & 105.90 & 199.50 & 115.00 \\
\hline
\end{tabular}

The data present the average values from three experiments.

\subsection{Anticancer Activity of the $\mathrm{WO}_{3}$ and Surface Functionalized $\mathrm{WO}_{3}-\mathrm{AAs} \mathrm{NPs}$}

MTT assay was applied to determine cell metabolic activity for testing the cytotoxicity of a certain compound or drug. Herein, we evaluated the anticancer effect of the modified $\mathrm{WO}_{3}$-Trp and $\mathrm{WO}_{3}$-Cys and NPs against various kinds of cancer cells, including MCF-7 caco-2 and HepG-2 cell lines in comparison with free forms of Cys and Trp AAs along with original $\mathrm{WO}_{3} \mathrm{NPs}$. We also investigated the effect of these compounds on WISH cells as a normal cell line. Our results indicate that the highest values of $\mathrm{IC}_{50}$ were found to be for normal cells, which refer to the highest safety of the applied modified NPs. As presented in Table 2, $\mathrm{IC}_{50}$ values for the modified $\mathrm{WO}_{3}$-Cys and $\mathrm{WO}_{3}$-Trp NPs against WISH cells were near those free forms of Cys, Trp, and $\mathrm{WO}_{3} \mathrm{NPs}$, which highlight their safety. 
Table 2. $\mathrm{EC}_{100}, \mathrm{IC}_{50}(\mu \mathrm{g} / \mathrm{mL})$, and SI values of the modified $\mathrm{WO}_{3}-\mathrm{Cys}$ and $\mathrm{WO}_{3}$-Trp $\mathrm{NPs}$ against WISH, MCF-7, Caco-2, and HepG-2 cell lines after treatment for $48 \mathrm{~h}$ in comparison with $\mathrm{WO}_{3} \mathrm{NPs}$ and free amino acids (Cys and Trp).

\begin{tabular}{|c|c|c|c|c|c|}
\hline Sample & & WISH & MCF-7 & Caco-2 & HepG-2 \\
\hline \multirow{2}{*}{$\mathrm{WO}_{3}$} & $\mathrm{IC}_{50}$ & $2315 \pm 224.3$ & $2805 \pm 196.6$ & $2238 \pm 210.4$ & $2517 \pm 232.5$ \\
\hline & SI & - & $0.83 \pm 0.08$ & $1.03 \pm 0.09$ & $0.92 \pm 0.1$ \\
\hline \multirow{2}{*}{ Cys } & $\mathrm{IC}_{50}$ & $2221 \pm 159.8$ & $2365 \pm 159.7$ & $2635 \pm 118.9$ & $2936 \pm 102.1$ \\
\hline & SI & - & $0.94 \pm 0.07$ & $0.84 \pm 0.05$ & $0.76 \pm 0.04$ \\
\hline \multirow{2}{*}{$\operatorname{Trp}$} & $\mathrm{IC}_{50}$ & $2064 \pm 197.5$ & $2210 \pm 156.9$ & $2084 \pm 188.4$ & $2958 \pm 134.7$ \\
\hline & SI & - & $0.93 \pm 0.07$ & $0.99 \pm 0.09$ & $0.69 \pm 0.06$ \\
\hline \multirow{2}{*}{$\mathrm{WO}_{3}-\mathrm{Cys}$} & $\mathrm{IC}_{50}$ & $2036 \pm 193.2$ & $92.53 \pm 5.2$ & $162.9 \pm 7.5$ & $184.5 \pm 12.4$ \\
\hline & SI & - & $22.01 \pm 0.01$ & $12.49 \pm 0.02$ & $11.04 \pm 0.01$ \\
\hline \multirow{2}{*}{$\mathrm{WO}_{3}-\operatorname{Trp}$} & $\mathrm{IC}_{50}$ & $2210 \pm 166.8$ & $147.5 \pm 9.7$ & $176.3 \pm 10.1$ & $202.6 \pm 15.3$ \\
\hline & SI & - & $14.98 \pm 0.03$ & $12.54 \pm 0.02$ & $10.91 \pm 0.17$ \\
\hline
\end{tabular}

All values were expressed as mean \pm SE.

Furthermore, MCF-7 cells are the most sensitive cells to treatment with both modified NPs. The modified $\mathrm{WO}_{3}-\mathrm{Cys} \mathrm{NPs}$ had an anticancer activity against MCF-7, Caco-2, and HepG-2 cells after treatment for $48 \mathrm{~h}$ at $\mathrm{IC}_{50}$ values evaluated to be $92.53 \pm 5.2,162.9 \pm 7.5$, and $184.5 \pm 12.4 \mu \mathrm{g} / \mathrm{mL}$, respectively, with SI values of $22.01 \pm 0.01,12.49 \pm 0.02$, and $11.04 \pm 0.01$, respectively. While after treatment with $\mathrm{WO}_{3}-\mathrm{AAs} \mathrm{NPs}$ for $48 \mathrm{~h}$, values of $\mathrm{IC}_{50}$ were calculated to be $147.5 \pm 9.7,176.3 \pm 10.1$, and $202.6 \pm 15.3 \mu \mathrm{g} / \mathrm{mL}$ against the same cell lines, respectively, with SI values of $14.98 \pm 0.03,12.54 \pm 0.02$, and $10.91 \pm 0.17$, respectively. Collectively, the results (Table 2) indicate that $\mathrm{WO}_{3}-\mathrm{Cys} \mathrm{NPs}$ displayed an anticancer activity higher than $\mathrm{WO}_{3}$-Trp NPs against all tested cells. The interaction of bare NPs to cellular components is indirect [32], where L-cysteine is known to improve the cellular uptake [61], hence the high activity of the $\mathrm{WO}_{3}-\mathrm{Cys} \mathrm{NPs}$ may be attributed to the high protonation effect of its SH group toward many intracellular proteins [62]. The results are in agreement with Kato et al. [63], which demonstrated the role of L-cysteine in suppressing cancer development through regulating the excess activity of kinases that enhance cancer progression. In addition, there was a significant increase in the anticancer activity of the modified $\mathrm{WO}_{3}-\mathrm{Cys}$ and $\mathrm{WO}_{3}$-Trp NPs against all tested cancer cells in a dose-dependent manner with high selectivity to cancer cells and high safety against normal cells (Figure 5). Figure 5 also confirms the apoptotic effect of the modified $\mathrm{WO}_{3}{ }^{-}$ AAs NPs and reveals the proportional changes in HepG-2 morphology using the nuclear stain method. HepG-2 cells were observed to lose their normal shape after treatment with both modified $\mathrm{WO}_{3} \mathrm{NPs}$ for $48 \mathrm{~h}$ as compared to reference cells. Figure 6 also indicates more fragmented HepG-2 chromatin with condensed nuclei in a dose-dependent manner. Furthermore, observed chromatin fragmentation, shedding of apoptotic bodies, and nuclear condensation were considered the major properties of the apoptotic pathway, which became more noticeable with increasing the dose of treatment than untreated cells. Figure 7 also confirms the effect of the modified $\mathrm{WO}_{3}-\mathrm{Cys}$ and $\mathrm{WO}_{3}$-Trp NPs on expression levels of E2F2, p53, and Bcl-2 genes in MCF-7, Caco-2, and HepG-2 cells as evaluated by real-time PCR in comparison with untreated cells as control and 5-fluorouracil (5-FU) treated cells as a standard drug. Figure 7 indicates that levels of expression of E2F2, Bcl-2 genes were found to be suppressed and down-regulated after treatment with both modified NPs more than 5-FU-treated cells. Furthermore, the expression level of the Bcl-2 gene was reduced in the treated cancer cells by around 2 folds more than control cells in contrast to the p53 expression level that enhanced over 5-8 folds in treated cells compared to untreated controls. Collectively, Figures 1-3 indicate the superiority of modified $\mathrm{WO}_{3}-\mathrm{Cys}_{\mathrm{NPs}}$ toward all tested cells over that of the modified $\mathrm{WO}_{3}$-Trp NPs. 

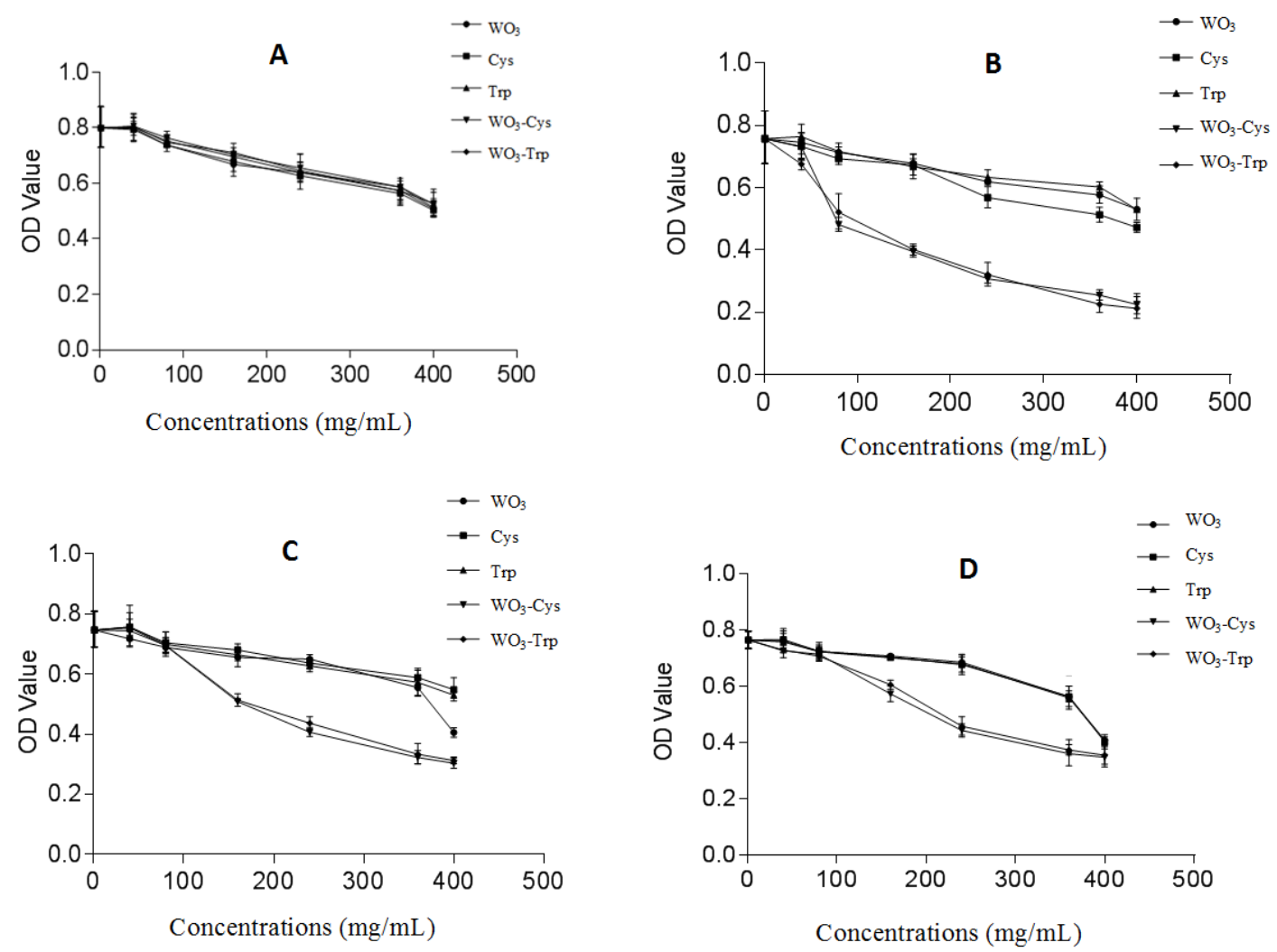

Figure 5. The dependence inhibition effect of the modified $\mathrm{WO}_{3} \mathrm{NPs}$ on the cell viability of the normal WISH cells (A), breast cancer MCF-7 cells (B), colon cancer Caco-2 cells (C), and hepatoma HepG-2 cells (D). Both normal cells and cancer cell lines were incubated with the $\mathrm{WO}_{3}$-AAs NPs at different concentrations $(0-0.5 \mathrm{mg} / \mathrm{mL})$ for $48 \mathrm{~h}$. All values are expressed as mean $\pm \mathrm{SE}$ and represent the average values from three experiments $(n=3)$.

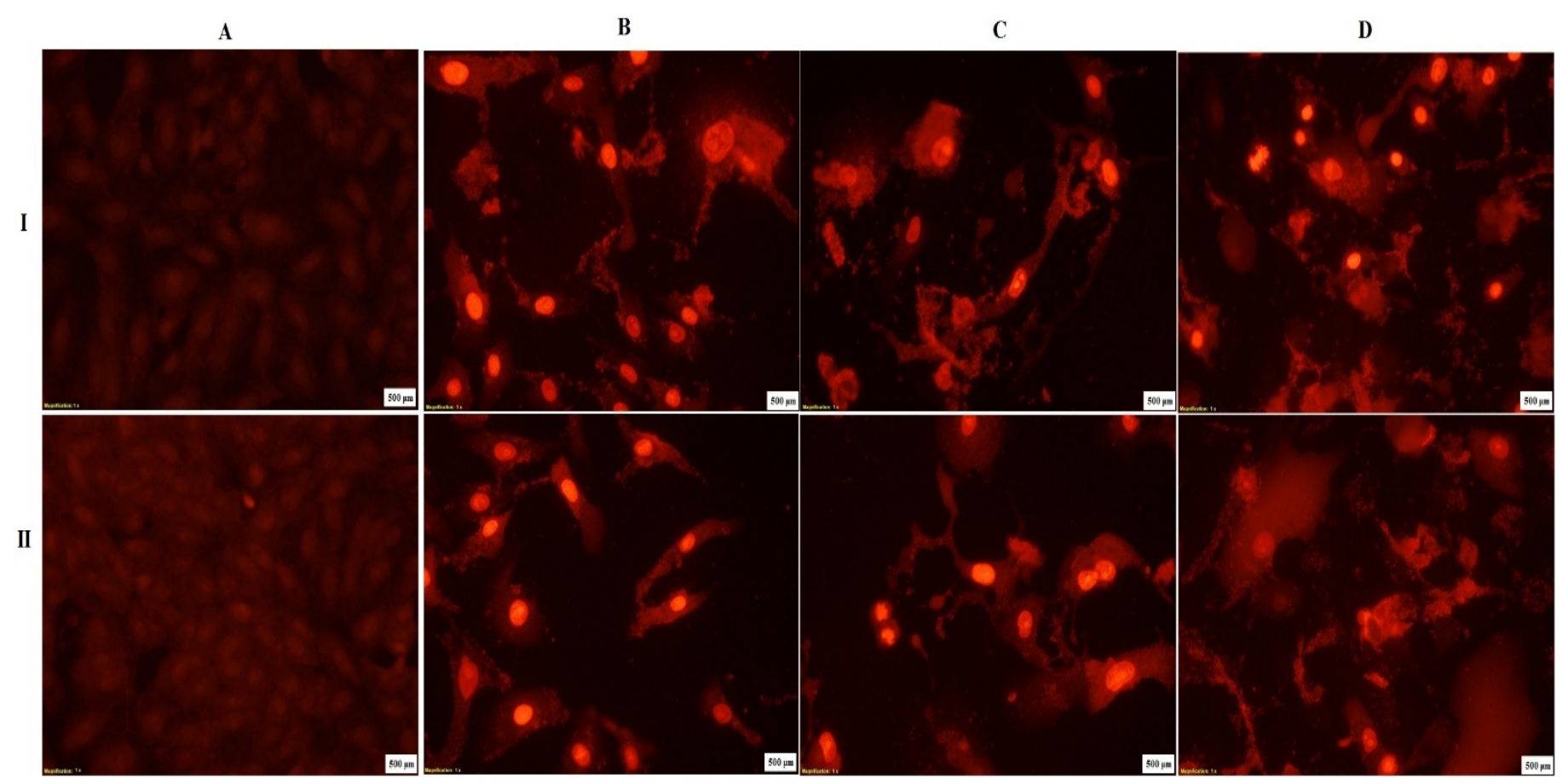

Figure 6. Fluorescence photograph of HepG-2 cells stained with PI dye under a fluorescence microscope after treatment with the modified $\mathrm{WO}_{3}$-Cys and $\mathrm{WO}_{3}$-Trp NPs (I and II, respectively). HepG-2 cells were exposed to different concentrations of $0.0,0.1,0.2$, and $0.3 \mathrm{mg} / \mathrm{mL}$ (A-D). The scale bar in all images is $500 \mu \mathrm{m}$. 

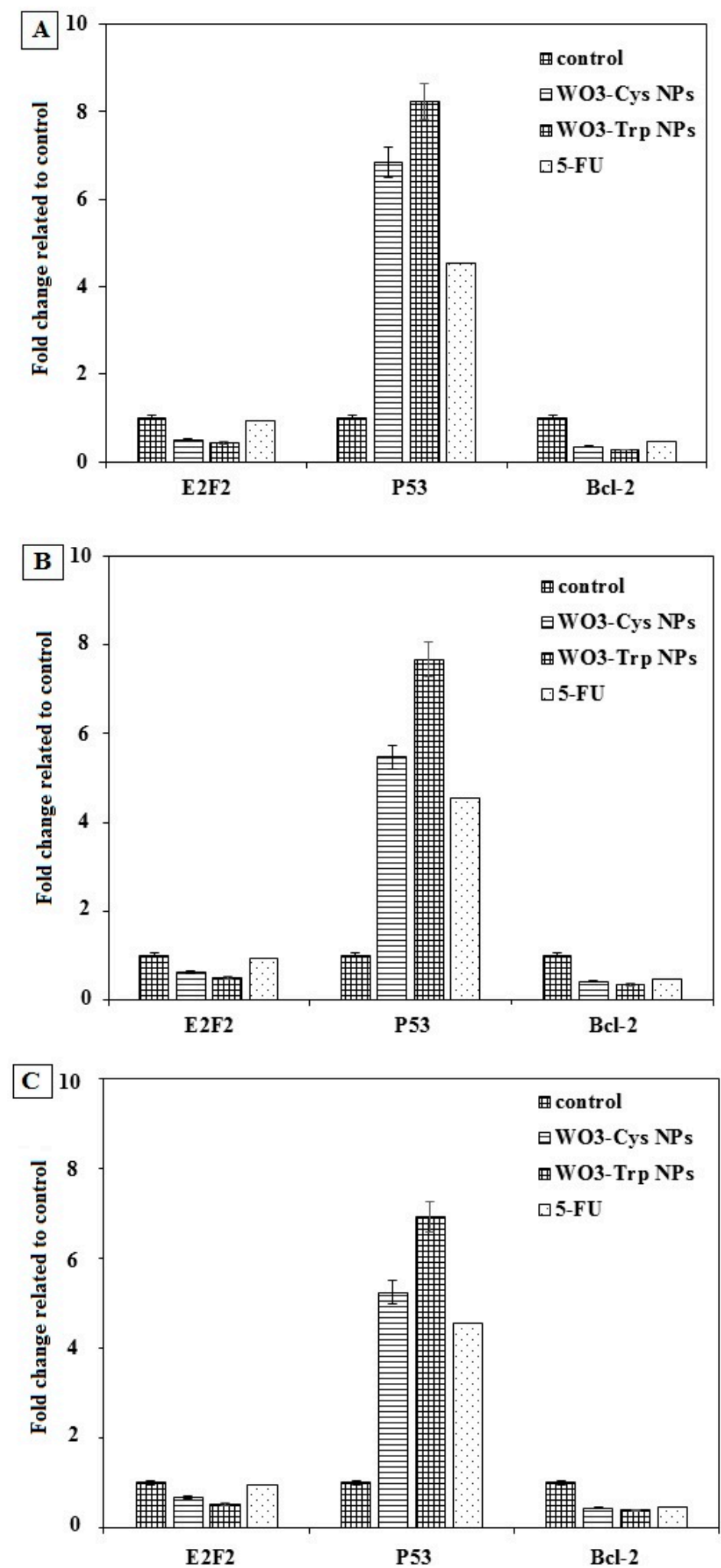

Figure 7. Effects of the modified $\mathrm{WO}_{3}-\mathrm{Cys}$ and $\mathrm{WO}_{3}-\operatorname{Trp} \mathrm{NPs}$ on the levels of E2F2, p53, and Bcl2 mRNA expression in MCF-7 cells (A), Caco-2 cells (B), and HepG-2 cells (C) treated with $\mathrm{IC}_{50}$ concentration of each modified NPs and 5-FU for $48 \mathrm{~h}$. The data are presented as mean $\pm \mathrm{SE}$ and represent the average values from three experiments $(n=3)$. 


\subsection{Molecular Docking Studies}

Molecular docking studies were carried out for the three compounds into three proteins, namely Bcl-2, p53, and E2F2, which are of crucial roles in cancer development [64-67]. The purpose was to get insights into the proposed targets of the studied compounds and to explore to what extent the modified NPs can accommodate the pocket and form interactions with the essential amino acid residues. The crystal structures of the three aforementioned proteins were downloaded from the protein data bank (PDB) website with ID 2W3L, 3ZME, and 5TUU, respectively.

For the Bcl-2 gene, the obtained results showed the significance of the binding of $\mathrm{WO}_{3}$-Trp to Bcl-2 through an arene proton interaction with the essential amino acid residue Tyr67 in the same manner as the ligand (Table 3). Further, an arene proton interaction was observed with the side chain of Met74. Additionally, it showed two hydrogen bonds (2.08 and $2.21 \AA$ ) with guanidine moiety of Arg105 (Figure 8A). At the same time, $\mathrm{WO}_{3}$ Cys NPs showed three hydrogen bonds with guanidine moiety of Arg88 (distances, 2.15, 2.16 and $2.40 \AA$ ). Moreover, an electrostatic interaction was observed between the thiol group of cysteine and alpha proton of Met74 (Figure $8 \mathrm{~B}$ ). While $\mathrm{WO}_{3} \mathrm{NPs}$ showed four hydrogen bonds with Bcl-2 protein, two of which were with the side-chain carboxylate of Glu95 (1.97 and $2.13 \AA$ ) and the other two were of distances of 2.21 and $3.23 \AA$ with backbone oxygen and mercapto group of Met74, respectively. Referring to p53 protein, the ligand was found to interact with three residues, Asp228, Cys229, and Thr230. The most significant binding pattern with p53 was that of $\mathrm{WO}_{3}-\mathrm{Cys} \mathrm{NPs}$, which accommodated the pocket showing interactions with the essential residues Cys229 and Thr230 as shown in Figure 8C. Electrostatic interaction with the beta carbon of Cys229 was observed. Two hydrogen bonds of 1.83 and $2.50 \AA$ length were formed with side chain $\mathrm{OH}$ and backbone $\mathrm{NH}$ of Thr230, respectively. Additionally, it showed an electrostatic interaction with the alkyl sidechain of Leu145. The second most promising interaction with p53 was that of $\mathrm{WO}_{3}$ NPs showing a hydrogen bond (distance: $2.26 \AA$ ) with the sidechain $\mathrm{OH}$ of the essential residue Thr230. Moreover, electrostatic interaction with the backbone oxygen of the effective residue Asp228 was observed. Further hydrogen bond (distance: $2.46 \AA$ ) was formed with the backbone oxygen of Val147 (Figure 8D). On the other side, the modified $\mathrm{WO}_{3}$-Trp was unable to accommodate the pocket of p53, showing a different binding mode rather than the ligand. However, it formed one hydrogen bond with Thr150 and another with Pro151. It also showed arene proton interactions with Thr150, Pro222, and Pro223.

Table 3. Binding free energies of the docked molecules.

\begin{tabular}{cccc}
\hline \multirow{2}{*}{ Compound. } & \multicolumn{3}{c}{ Binding Energy (Kcal/mol) } \\
\cline { 2 - 4 } & Bcl-2 (2W3L) & p53 (3ZME) & E2F2 (5TUU) \\
\hline Ligand & -5.23 & -7.14 & No ligand \\
\hline $\mathrm{WO}_{3} \mathrm{NPs}$ & -6.05 & -46.45 & -4.03 \\
\hline $\mathrm{WO}_{3}$-Trp nanocomposite & -6.54 & -38.97 & -6.22 \\
\hline $\mathrm{WO}_{3}$-Cys nanocomposite & -7.21 & -49.00 & -3.09 \\
\hline
\end{tabular}




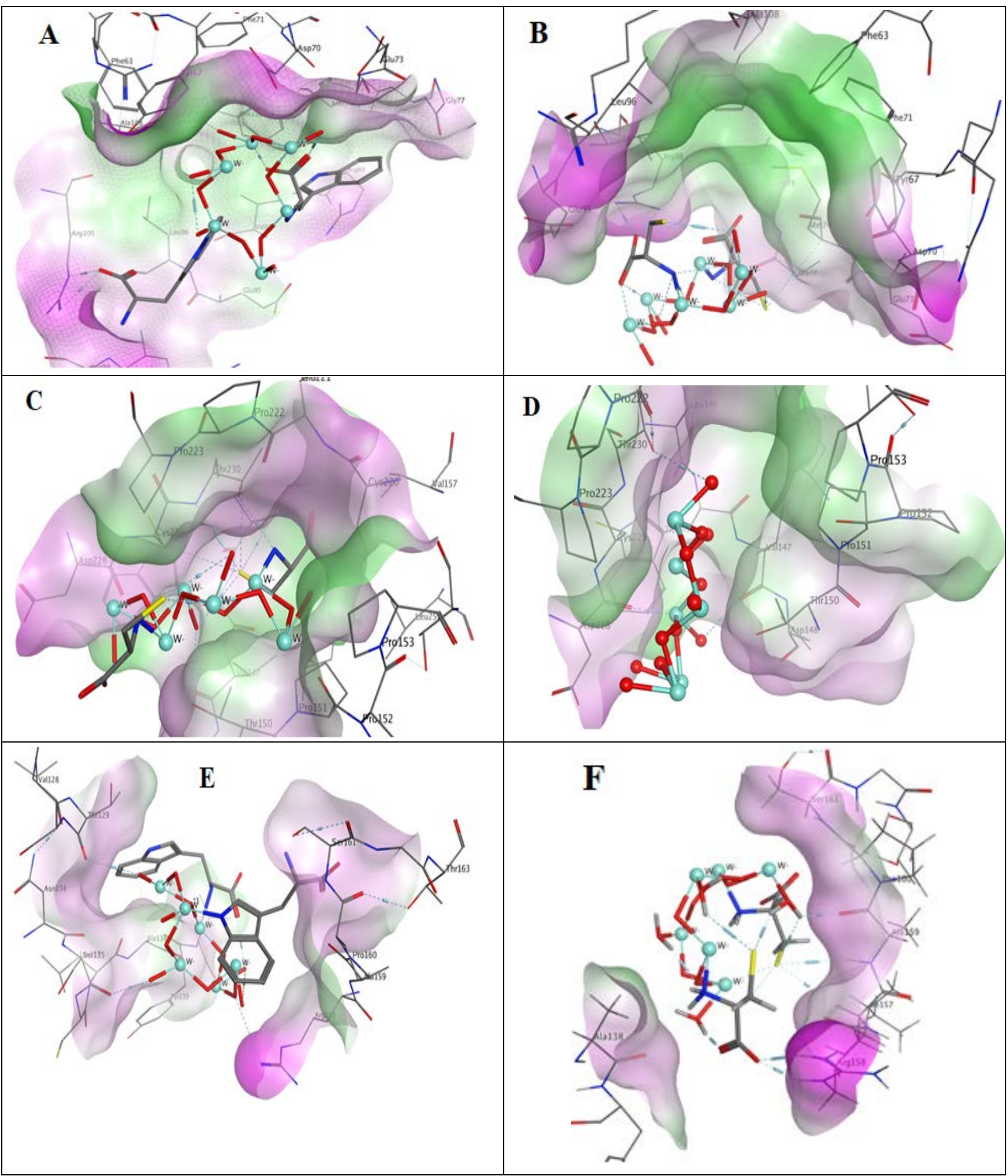

Figure 8. 3D interaction of (A) $\mathrm{WO}_{3}$-Trp nanocomposite with Bcl-2 protein, (B) $\mathrm{WO}_{3}-\mathrm{Cys}$ nanocomposite with $\mathrm{Bcl}-2$ protein, (C) $\mathrm{WO}_{3}$-Trp nanocomposite with p53 protein, (D) $\mathrm{WO}_{3} \mathrm{NPs}$ with p53 protein, (E) $\mathrm{WO}_{3}$-Trp nanocomposite with E2F2 protein, (F) $\mathrm{WO}_{3}$-Cys nanocomposite with $\mathrm{E} 2 \mathrm{~F} 2$ protein.

Finally, the E2F2 protein was reported to have four domains: DNA-binding domain, a dimerization domain, a transactivation domain, and a pocket protein binding domain [68]. The amino acid residues from 86 to 195 construct the dimerization domain. These residues are responsible for the formation of heterodimers with a DP family protein [68]. 5TUU at 
the PDB website is the crystal structure of the E2F2-DP1 coiled-coil. Docking results into this protein showed three hydrogen bonds for $\mathrm{WO}_{3}$-Trp NPs as illustrated in Figure 8E. The first (distance: $2.65 \AA$ ) was with guanidine moiety of Arg158. The second was of $2.21 \AA$ length, with the backbone oxygen of Ser135. The third one (distance: $2.28 \AA$ ) was observed with the backbone oxygen of Thr129. Moreover, an arene proton interaction was formed with Ala138. Regarding the $\mathrm{WO}_{3}$-Cys composite, Figure $8 \mathrm{~F}$ shows four hydrogen bonds, two of which were of 2.07 and $2.17 \AA$ A lengths with guanidine moiety of Arg158. Another hydrogen bond ( $2.19 \AA$ length) can be observed with the backbone oxygen of Ala159. The fourth one was of $3.14 \AA$ length, with the backbone $\mathrm{NH}$ of Ala159. $\mathrm{WO}_{3} \mathrm{NPs}$ showed one hydrogen bond ( $2.01 \AA$ length) with the sidechain $\mathrm{OH}$ of Thr163. It also showed another hydrogen bond of $2.01 \AA$ length with the backbone oxygen of Ala159.

\section{Conclusions}

Tungsten oxide $\left(\mathrm{WO}_{3}\right)$ represents one of the most interesting metal oxides with various potential industrial applications. In this work, $\mathrm{WO}_{3}$ nanosheets were prepared in one step through a cation exchange column and characterized via different methods. The surface modification of the prepared $\mathrm{WO}_{3} \mathrm{NPs}$ with either L-tryptophan or L-cysteine greatly enhanced their biological activities. The prepared $\mathrm{WO}_{3}$-Trp and $\mathrm{WO}_{3}$-Cys exhibited strong dye removal activity toward methylene blue and safranin dyes with complete dye removal $(100 \%)$ after $6 \mathrm{~h}$. The antimicrobial activity assessment revealed broadspectrum antimicrobial activity toward the three applied organisms: Staphylococcus aureus and Pseudomonas aeruginosa, and Candida albicans with higher antibacterial activity from $\mathrm{WO}_{3}$-Cys and potent antifungal activity through $\mathrm{WO}_{3}$-Trp. The dye removal activity in addition to the antibacterial activity of the newly prepared $\mathrm{WO}_{3}-\mathrm{AA}$ NPs could privilege their application in the dentistry field for dye removal and management of the oral bacterial infection. The results also indicate a remarkable antitumor activity in a dose-dependent manner through $\mathrm{WO}_{3}$-Trp and $\mathrm{WO}_{3}$-Cys toward all applied tumor cell lines (MCF-7, Caco2 , and HepG-2) attributed to induction of apoptotic effects. The highest antitumor activity was against the breast cancer tumor cell MCF-7. $\mathrm{WO}_{3}-\mathrm{Cys}$ revealed the superior antitumor activity, which could be attributed to the remarkable activity of the thiol group, as indicated in the molecular docking studies. Collectively, the surface modification of $\mathrm{WO}_{3} \mathrm{NPs}$ with amino acids, especially that of L-tryptophan or L-cysteine, significantly enhanced their biological activities and may expand their industrial applications.

Author Contributions: Conceptualization, A.I.A.-E., H.E.-G. and E.M.E.-F.; Data curation, A.I.A.-E., A.E.A. and E.M.E.-F.; Formal analysis, A.I.A.-E., H.E.-G., A.E.A. and E.M.E.-F.; Investigation, A.I.A.-E., H.E.-G. and E.M.E.-F.; Methodology, A.I.A.-E., H.E.-G., A.E.A. and E.M.E.-F.; Software, A.E.A. and E.M.E.-F.; Supervision, H.E.-G. and E.M.E.-F.; Validation, H.E.-G. and E.M.E.-F.; Visualization, H.E.-G. and E.M.E.-F.; Writing-original draft, A.I.A.-E., H.E.-G., A.E.A. and E.M.E.-F.; Writing—review \& editing, A.I.A.-E., H.E.-G., A.E.A. and E.M.E.-F. All authors have read and agreed to the published version of the manuscript.

Funding: This study did not receive any specific grant from funding agencies in the public, commercial, or not-for-profit sectors.

Institutional Review Board Statement: Not applicable.

Informed Consent Statement: Not applicable.

Data Availability Statement: The data presented in this study are available on request from the corresponding author.

Conflicts of Interest: The authors declare that they have no competing interest. 


\section{References}

1. Yang, M.; Shrestha, N.K.; Schmuki, P. Thick porous tungsten trioxide films by anodization of tungsten in fluoride containing phosphoric acid electrolyte. Electrochem. Commun. 2009, 11, 1908-1911. [CrossRef]

2. Lee, S.H.; Deshpande, R.; Parilla, P.A.; Jones, K.M.; To, B.; Mahan, A.H.; Dillon, A.C. Crystalline $\mathrm{WO}_{3}$ nanoparticles for highly improved electrochromic applications. Adv. Mater. 2006, 18, 763-766. [CrossRef]

3. Qi, H.; Wolfe, J.; Wang, D.; Fan, H.J.; Fichou, D.; Chen, Z. Triple-layered nanostructured $\mathrm{WO}_{3}$ photoanodes with enhanced photocurrent generation and superior stability for photoelectrochemical solar energy conversion. Nanoscale 2014, 6, 13457-13462. [CrossRef]

4. Prabhu, N.; Agilan, S.; Muthukumarasamy, N.; Senthil, T.S. Enhanced photovoltaic performance of $\mathrm{WO}_{3}$ nanoparticles added dye sensitized solar cells. J. Mater. Sci. Mater. Electron. 2014, 25, 5288-5295. [CrossRef]

5. Li, J.; Huang, J.; Wu, J.; Cao, L.; Li, Q.; Yanagisawa, K. Microwave-assisted growth of $\mathrm{WO}_{3} \cdot 0.33 \mathrm{H}_{2} \mathrm{O}$ micro/nanostructures with enhanced visible light photocatalytic properties. CrystEngComm 2013, 15, 7904-7913. [CrossRef]

6. Li, J.; Liu, X.; Cui, J.; Sun, J. Hydrothermal synthesis of self-assembled hierarchical tungsten oxides hollow spheres and their gas sensing properties. ACS Appl. Mater. Interfaces 2015, 7, 10108-10114. [CrossRef] [PubMed]

7. Wang, C.; Li, X.; Feng, C.; Sun, Y.; Lu, G. Nanosheets assembled hierarchical flower-like $\mathrm{WO}_{3}$ nanostructures: Synthesis, characterization, and their gas sensing properties. Sens. Actuators B Chem. 2015, 210, 75-81. [CrossRef]

8. Zhou, J.; Ding, Y.; Deng, S.Z.; Gong, L.; Xu, N.S.; Wang, Z.L. Three-dimensional tungsten oxide nanowire networks. Adv. Mater. 2005, 17, 2107-2110. [CrossRef]

9. Slimani, Y.; Almessiere, M.A.; Hannachi, E.; Mumtaz, M.; Manikandan, A.; Baykal, A.; Ben Azzouz, F. Improvement of flux pinning ability by tungsten oxide nanoparticles added in $\mathrm{YBa}_{2} \mathrm{Cu}_{3} \mathrm{O}$ y superconductor. Ceram. Int. 2019, 45, 6828-6835. [CrossRef]

10. Suda, Y.; Kawasaki, H.; Ohshima, T.; Yagyuu, Y. Characteristics of tungsten oxide thin films prepared on the flexible substrates using pulsed laser deposition. Thin Solid Films 2008, 516, 4397-4401. [CrossRef]

11. Park, S.M.; Nam, C. Dye-adsorption properties of $\mathrm{WO}_{3}$ nanorods grown by citric acid assisted hydrothermal methods. Ceram. Int 2017, 43, 17022-17025. [CrossRef]

12. Zhuzhelskii, D.V.; Tolstopjatova, E.G.; Volkov, A.I.; Eliseeva, S.N.; Láng, G.G.; Kondratiev, V.V. Insights on the electrodeposition mechanism of tungsten oxide into conducting polymers: Potentiostatic vs. potentiodynamic deposition. Synth. Met. 2020, 267, 116469. [CrossRef]

13. Sun, Q.; Xiao, F.; Ren, S.; Dong, Z.; Wang, J.; Su, X. Hydrothermal synthesis of $\mathrm{WO}_{3}$ nanorods and their performance in the adsorption of Rhodamine B and the synthesis of adipic acid. Ceram. Int. 2014, 40, 11447-11451. [CrossRef]

14. Wang, Z.; Zhou, S.; Wu, L. Preparation of rectangular $\mathrm{WO}_{3}-\mathrm{H}_{2} \mathrm{O}$ nanotubes under mild conditions. Adv. Funct. Mater. 2007, 17, 1790-1794. [CrossRef]

15. Lu, N.; Yang, C.; Liu, P.; Su, X. Preparation of $2 \mathrm{~nm}$ tungsten oxide nanowires based on two-phase strategy and their ultra-sensitive $\mathrm{NO}_{2}$ gas sensing properties. J. Colloid Interface Sci. 2019, 557, 311-317. [CrossRef] [PubMed]

16. Hu, X.; Ji, Q.; Hill, J.P.; Ariga, K. Large-scale synthesis of WOx-EDA nanobelts and their application as photoswitches. CrystEngComm 2011, 13, 2237-2241. [CrossRef]

17. Garcia, I.T.S.; Corrêa, D.S.; de Moura, D.S.; Pazinato, J.C.O.; Pereira, M.B.; da Costa, N.B.D. Multifaceted tungsten oxide films grown by thermal evaporation. Surf. Coat. Technol. 2015, 283, 177-183. [CrossRef]

18. Ji, R.; Zheng, D.; Zhou, C.; Cheng, J.; Yu, J.; Li, L. Low-temperature preparation of tungsten oxide anode buffer layer via ultrasonic spray pyrolysis method for large-area organic solar cells. Materials 2017, 10, 820. [CrossRef] [PubMed]

19. Au, B.W.C.; Chan, K.Y.; Pang, W.L.; Lee, C.L.; Mustafa, A.H. Tungsten oxide $\left(\mathrm{WO}_{3}\right)$ films prepared by sol-gel spin-coating technique. Solid State Phenom. 2018, 280, 71-75. [CrossRef]

20. Sadakane, M.; Sasaki, K.; Kunioku, H.; Ohtani, B.; Ueda, W.; Abe, R. Preparation of nano-structured crystalline tungsten(VI) oxide and enhanced photocatalytic activity for decomposition of organic compounds under visible light irradiation. Chem. Commun. 2008, 1, 6552-6554. [CrossRef]

21. Das, P.K.; Arunachalam, M.; Seo, Y.J.; Ahn, K.-S.; Ha, J.-S.; Kang, S.H. Functional Blocking Layer of Twisted Tungsten Oxide Nanorod Grown by Electrochemical Anodization for Photoelectrochemical Water Splitting. J. Electrochem. Soc. 2020, 167, 066501. [CrossRef]

22. Hidayat, D.; Purwanto, A.; Wang, W.N.; Okuyama, K. Preparation of size-controlled tungsten oxide nanoparticles and evaluation of their adsorption performance. Mater. Res. Bull. 2010, 45, 165-173. [CrossRef]

23. Nagyné-Kovács, T.; Lukács, I.E.; Szabó, A.; Hernadi, K.; Igricz, T.; László, K.; Szilágyi, I.M.; Pokol, G. Effect of pH in the hydrothermal preparation of monoclinic tungsten oxide. J. Solid State Chem. 2020, 281, 1-7. [CrossRef]

24. Jamal, M.; Razeeb, K.M.; Shao, H.; Islam, J.; Akhter, I.; Furukawa, H.; Khosla, A. Development of Tungsten Oxide Nanoparticle Modified Carbon Fibre Cloth as Flexible pH Sensor. Sci. Rep. 2019, 9, 4659. [CrossRef] [PubMed]

25. Panda, S.K.; Aggarwal, I.; Kumar, H.; Prasad, L.; Kumar, A.; Sharma, A.; Vo, D.V.N.; Van Thuan, D.; Mishra, V. Magnetite Nanoparticles as Sorbents for Dye Removal: A Review; Springer International Publishing: Cham, Switzerland, 2021. ISBN 0123456789.

26. Cronholm, P.; Karlsson, H.L.; Hedberg, J.; Lowe, T.A.; Winnberg, L.; Elihn, K.; Wallinder, I.O.; Möller, L. Intracellular uptake and toxicity of $\mathrm{Ag}$ and $\mathrm{CuO}$ nanoparticles: A comparison between nanoparticles and their corresponding metal ions. Small 2013, 9, 970-982. [CrossRef] [PubMed] 
27. Agnihotri, R.; Gaur, S.; Albin, S. Nanometals in Dentistry: Applications and Toxicological Implications-A Systematic Review. Biol. Trace Elem. Res. 2020, 197, 70-88. [CrossRef] [PubMed]

28. Baek, Y.-W.; An, Y.-J. Microbial toxicity of metal oxide nanoparticles ( $\mathrm{CuO}, \mathrm{NiO}, \mathrm{ZnO}$, and $\left.\mathrm{Sb}_{2} \mathrm{O}_{3}\right)$ to Escherichia coli, Bacillus subtilis, and Streptococcus aureus. Sci. Total Environ. 2011, 409, 1603-1608. [CrossRef]

29. Miller, P.J.; Shantz, D.F. Covalently functionalized uniform amino-silica nanoparticles. Synthesis and validation of amine group accessibility and stability. Nanoscale Adv. 2020, 2, 860-868. [CrossRef]

30. EL-Fakharany, E.M.; Abd-Elhamid, A.I.; El-Deeb, N.M. Preparation and characterization of novel nanocombination of bovine lactoperoxidase with Dye Decolorizing and anti-bacterial activity. Sci. Rep. 2019, 9, 8530. [CrossRef]

31. Havaldar, D.V.; Patil, R.V.; Moholkar, D.N.; Magdum, P.S.; Vadrale, A.P.; Pawar, K.D. Differently synthesized gold nanoparticles respond differently to functionalization with L-amino acids. Particuology 2020, 52, 97-104. [CrossRef]

32. Saptarshi, S.R.; Duschl, A.; Lopata, A.L. Interaction of nanoparticles with proteins: Relation to bio-reactivity of the nanoparticle. J. Nanobiotechnol. 2013, 11, 1-12. [CrossRef]

33. Sarkar, S.; Ponce, N.T.; Banerjee, A.; Bandopadhyay, R.; Rajendran, S.; Lichtfouse, E. Green polymeric nanomaterials for the photocatalytic degradation of dyes: A review. Environ. Chem. Lett. 2020, 18, 1569-1580. [CrossRef]

34. El-Fakharany, E.M. Nanoformulation of lactoferrin potentiates its activity and enhances novel biotechnological applications. Int. J. Biol. Macromol. 2020, 165, 970-984. [CrossRef] [PubMed]

35. El-Fakharany, E.M. Nanoformulation approach for improved stability and efficiency of lactoperoxidase. Prep. Biochem. Biotechnol. 2020, 51, 1-13. [CrossRef]

36. Jiang, T.; Zhang, L.; Ji, M.; Wang, Q.; Zhao, Q.; Fu, X.; Yin, H. Carbon nanotubes $/ \mathrm{TiO}_{2}$ nanotubes composite photocatalysts for efficient degradation of methyl orange dye. Particuology 2013, 11, 737-742. [CrossRef]

37. Marcelo, L.R.; de Gois, J.S.; da Silva, A.A.; Cesar, D.V. Synthesis of Iron-Based Magnetic Nanocomposites and Applications in Adsorption Processes for Water Treatment: A Review; Springer International Publishing: Cham, Switzerland, 2020. ISBN 0123456789.

38. Harding, M.C.; Sloan, C.D.; Merrill, R.M.; Harding, T.M.; Thacker, B.J.; Thacker, E.L. Transitions from Heart Disease to Cancer as the Leading Cause of Death in US States, 1999-2016. Prev. Chronic Dis. 2018, 15, E158. [CrossRef]

39. Siegel, R.L.; Miller, K.D.; Jemal, A. Cancer statistics, 2020. CA Cancer J. Clin. 2020, 70, 7-30. [CrossRef] [PubMed]

40. Holland, T.; Fowler, V.G.; Shelburne, S.A. Invasive gram-positive bacterial infection in cancer patients. Clin. Infect. Dis. 2014, 59, S331-S334. [CrossRef] [PubMed]

41. Aydin Sevinç, B.; Hanley, L. Antibacterial activity of dental composites containing zinc oxide nanoparticles. J. Biomed. Mater. Res. B. Appl. Biomater. 2010, 94, 22-31. [CrossRef]

42. Tang, Z.X.; Lv, B.F. MgO nanoparticles as antibacterial agent: Preparation and activity. Braz. J. Chem. Eng. 2014, 31, 591-601. [CrossRef]

43. Feng, X.; Jin, S.; Wang, M.; Pang, Q.; Liu, C.; Liu, R.; Wang, Y.; Yang, H.; Liu, F.; Liu, Y. The Critical Role of Tryptophan in the Antimicrobial Activity and Cell Toxicity of the Duck Antimicrobial Peptide DCATH. Front. Microbiol. 2020, 11, 1146. [CrossRef]

44. Costa, D.; Savio, L.; Pradier, C.M. Adsorption of Amino Acids and Peptides on Metal and Oxide Surfaces in Water Environment: A Synthetic and Prospective Review. J. Phys. Chem. B 2016, 120, 7039-7052. [CrossRef]

45. Ustunol, I.B.; Gonzalez-Pech, N.I.; Grassian, V.H. pH-dependent adsorption of $\alpha$-amino acids, lysine, glutamic acid, serine and glycine, on $\mathrm{TiO}_{2}$ nanoparticle surfaces. J. Colloid Interface Sci. 2019, 554, 362-375. [CrossRef] [PubMed]

46. Tsai, Y.C.; Tang, C.C.; Wu, H.H.; Wang, Y.S.; Chen, Y.F. Antibacterial Activity of Cysteine-Derived Cationic Dipeptides. Int. J. Pept. Res. Ther. 2020, 26, 1107-1114. [CrossRef]

47. Bi, X.; Wang, C.; Ma, L.; Sun, Y.; Shang, D. Investigation of the role of tryptophan residues in cationic antimicrobial peptides to determine the mechanism of antimicrobial action. J. Appl. Microbiol. 2013, 115, 663-672. [CrossRef] [PubMed]

48. El-Fakharany, E.M.; Abu-Elreesh, G.M.; Kamoun, E.A. Protein extracted from a bacterial silk-like. RSC Adv. 2020, 10, 5098-5107. [CrossRef]

49. Abu-Serie, M.M.; El-Fakharany, E.M. Efficiency of novel nanocombinations of bovine milk proteins (lactoperoxidase and lactoferrin) for combating different human cancer cell lines. Sci. Rep. 2017, 7, 16769. [CrossRef] [PubMed]

50. El-Fakharany, E.M.; Abu-Serie, M.M.; Litus, E.A.; Permyakov, S.E.; Permyakov, E.A.; Uversky, V.N.; Redwan, E.M. The Use of Human, Bovine, and Camel Milk Albumins in Anticancer Complexes with Oleic Acid. Protein J. 2018, 37, 203-215. [CrossRef]

51. Abdallah, A.E.; Eissa, S.I.; Al Ward, M.M.S.; Mabrouk, R.R.; Mehany, A.B.M.; El-Zahabi, M.A. Design, synthesis and molecular modeling of new quinazolin-4 $(3 \mathrm{H})$-one based VEGFR-2 kinase inhibitors for potential anticancer evaluation. Bioorg. Chem. 2021, 109, 104695. [CrossRef]

52. Mudunkotuwa, I.A.; Grassian, V.H. Histidine adsorption on $\mathrm{TiO}_{2}$ nanoparticles: An integrated spectroscopic, thermodynamic, and molecular-based approach toward understanding nano-bio interactions. Langmuir 2014, 30, 8751-8760. [CrossRef]

53. Mahmoudi, M.; Bombelli, F.B.; Lynch, I.; Ejtehadi, M.R.; Laurent, S.; Monopoli, M.P. Protein-Nanoparticle interactions: Opportunities and challenges. Chem. Rev. 2011, 111, 5610-5637. [CrossRef] [PubMed]

54. Luo, J.Y.; Lin, Y.R.; Liang, B.W.; Li, Y.D.; Mo, X.W.; Zeng, Q.G. Controllable dye adsorption behavior on amorphous tungsten oxide nanosheet surfaces. RSC Adv. 2015, 5, 100898-100904. [CrossRef]

55. Jeevitha, G.; Abhinayaa, R.; Mangalaraj, D.; Ponpandian, N. Tungsten oxide-graphene oxide $\left(\mathrm{WO}_{3}-\mathrm{GO}\right)$ nanocomposite as an efficient photocatalyst, antibacterial and anticancer agent. J. Phys. Chem. Solids 2018, 116, 137-147. [CrossRef] 
56. Dinari, M.; Momeni, M.M.; Ahangarpour, M. Efficient degradation of methylene blue dye over tungsten trioxide/multi-walled carbon nanotube system as a novel photocatalyst. Appl. Phys. A Mater. Sci. Process. 2016, 122, 1-9. [CrossRef]

57. Liu, Y.; Yang, K.; Jia, Y.; Shi, J.; Tong, Z.; Wang, Z. Cysteine potentiates bactericidal antibiotics activity against gram-negative bacterial persisters. Infect. Drug Resist. 2020, 13, 2593-2599. [CrossRef] [PubMed]

58. Epand, R.M.; Walker, C.; Epand, R.F.; Magarvey, N.A. Molecular mechanisms of membrane targeting antibiotics. Biochim. Biophys. Acta Biomembr. 2016, 1858, 980-987. [CrossRef] [PubMed]

59. Du, X.; Yin, S.; Xu, L.; Ma, J.; Yu, H.; Wang, G.; Li, J. Polylysine and cysteine functionalized chitosan nanoparticle as an efficient platform for oral delivery of paclitaxel. Carbohydr. Polym. 2020, 229, 115484. [CrossRef]

60. Chan, D.I.; Prenner, E.J.; Vogel, H.J. Tryptophan- and arginine-rich antimicrobial peptides: Structures and mechanisms of action. Biochim. Biophys. Acta Biomembr. 2006, 1758, 1184-1202. [CrossRef]

61. Wu, S.Y.; Chou, H.Y.; Tsai, H.C.; Anbazhagan, R.; Yuh, C.H.; Yang, J.M.; Chang, Y.H. Amino acid-modified PAMAM dendritic nanocarriers as effective chemotherapeutic drug vehicles in cancer treatment: A study using zebrafish as a cancer model. RSC Adv. 2020, 10, 20682-20690. [CrossRef]

62. Borenfreund, E.; Puerner, J.A. A simple quantitative procedure using monolayer cultures for cytotoxicity assays (HTD/NR-90). J. Tissue Cult. Methods 1985, 9, 7-9. [CrossRef]

63. Kato, M.; Kumasaka, M.Y.; Takeda, K.; Hossain, K.; Iida, M.; Yajima, I.; Goto, Y.; Ohgami, N. L-cysteine as a regulator for arsenic-mediated cancer-promoting and anti-cancer effects. Toxicol. In Vitro 2011, 25, 623-629. [CrossRef] [PubMed]

64. Gascoyne, R.D.; Adomat, S.A.; Krajewski, S.; Krajewska, M.; Horsman, D.E.; Tolcher, A.W.; O’Reilly, S.E.; Hoskins, P.; Coldman, A.J.; Reed, J.C.; et al. Prognostic significance of Bcl-2 protein expression and Bcl-2 gene rearrangement in diffuse aggressive non-Hodgkin's lymphoma. Blood 1997, 90, 244-251. [CrossRef] [PubMed]

65. Bodner, S.M.; Minna, J.D.; Jensen, S.M.; D’Amico, D.; Carbone, D.; Mitsudomi, T.; Fedorko, J.; Buchhagen, D.L.; Nau, M.M.; Gazdar, A.F. Expression of mutant p53 proteins in lung cancer correlates with the class of p53 gene mutation. Oncogene 1992, 7, 743-749. [PubMed]

66. Garneau, H.; Paquin, M.C.; Carrier, J.C.; Rivard, N. E2F4 expression is required for cell cycle progression of normal intestinal crypt cells and colorectal cancer cells. J. Cell. Physiol. 2009, 221, 350-358. [CrossRef] [PubMed]

67. Joensuu, H.; Pylkkänen, L.; Toikkanen, S. Bcl-2 protein expression and long-term survival in breast cancer. Am. J. Pathol. 1994, 145, 1191-1198. [PubMed]

68. Hsu, J.; Sage, J. Novel functions for the transcription factor E2F4 in development and disease. Cell Cycle 2016, 15, 3183-3190. [CrossRef] [PubMed] 